\section{Hoall}

hjuoz.uoz.edu.krd p-ISSN: 2664-4673 e-ISSN: 2664-4681
كَوْقارا زانستيّن مروّقايهتى يا زانكوّيا زاخوّ

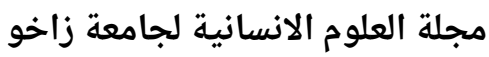

Humanities Journal of University of Zakho (HJUOZ)

Vol. 7, No. 1, pp. 30-42, March.-2019

رهنكثهدانا موّركيّ شاهدبازى و لهشكهريىّ سهبكى خوراسانى د شعرا كلاسيكيا كورديدار

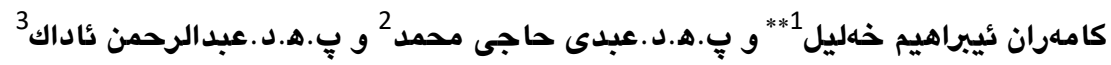

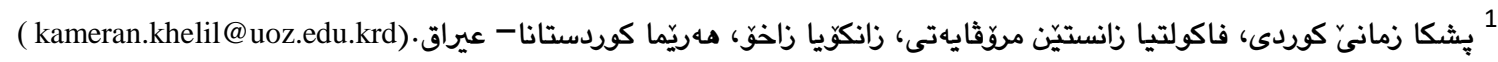

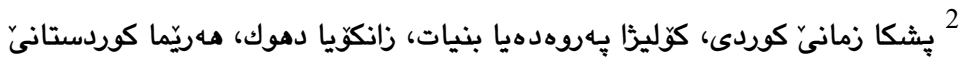

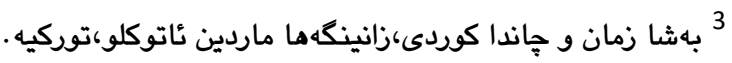

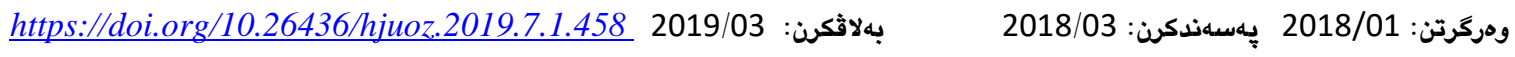

"ِوَخته:

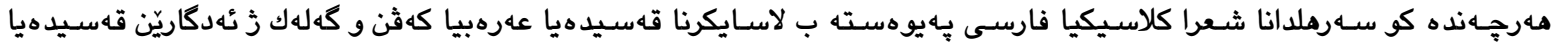

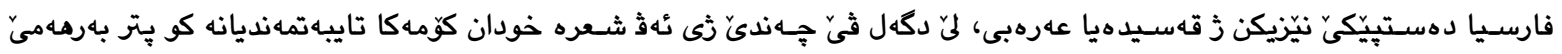

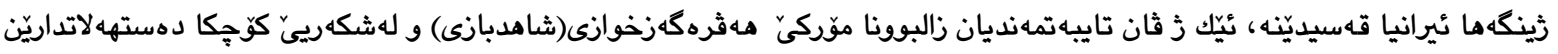

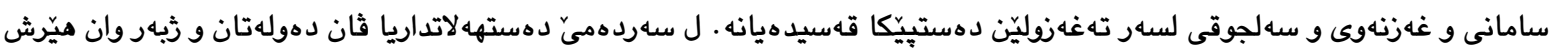

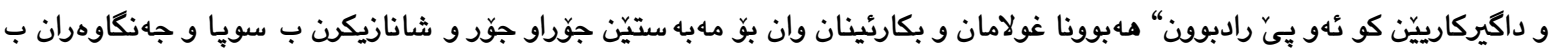

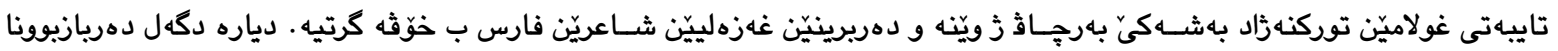

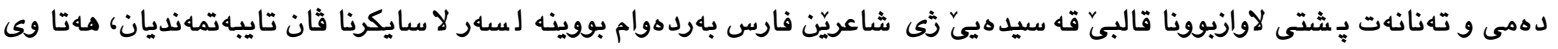

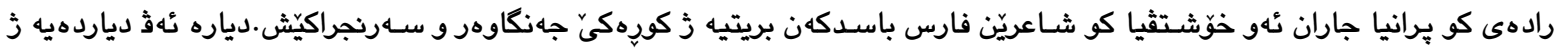

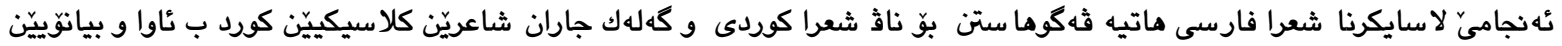

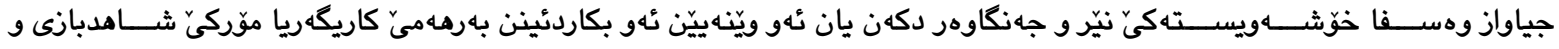
له شكهرييّ قهسيدهيا سهبكيّ خوراسانينه.

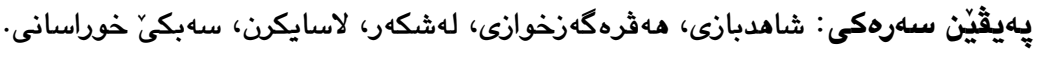

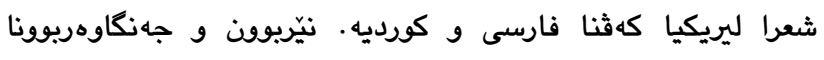

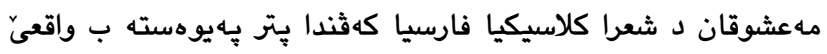

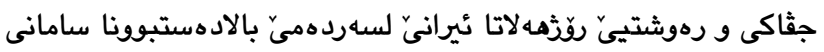
و غهزنهوى و سهلجوقيان، لي بهردهامبوونا ثى نهريتى ل شعرا

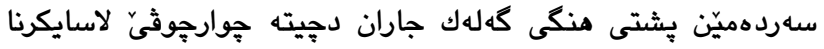
نهريتيّن شعرا رِّدهه لاتا ئيسلاميدا و ب تايبهت شعرا سهبكيّ خوراسانى،

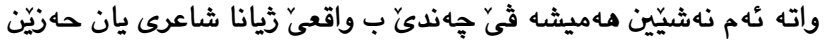

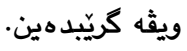

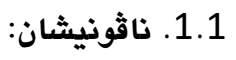

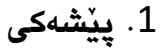

لاسايكرنا شاعرين كلاسيكييّن كورد ذ شعرا كلاسيكيا فارسى بابهتهكيّ

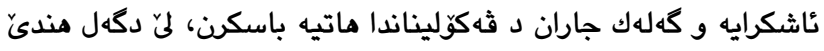

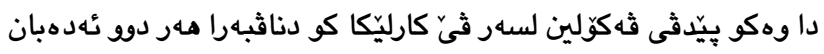

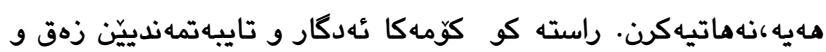
بهرجاث دناثبهرا شعرا كلاسيكيا ههر دوق زماناندا ههنه، لمن كومهكا ئهدكار و تاييهتمهنديين دى ثى هلنه كو كهلهك بهرجسته نينن و ثهكولهران يان هـست ب هدبوونا وان نهكريه يان ثبهر هندهك ئهكهريّن تايبهتى نهثياينه باسى وان بكهن، دياره ئيّك ز ثان بابهتان شاهدبازى(هه ثرهكهزخوانى) و لهشكه ركهرايا زاله لسهر تابلويا دلداريا 
ئورويا و ئهفريقا و ناسيا دهستهلاتا سياسى و نايينى ههلويستيّن جياواز ل ههمبهر ثيّ يهكيّ ههبووينه؛ بو نموونه ثيانا هـثرهكهزى ل يونانا كهثن هـبوويه و ب عهشقا ئهفلاتونى هاتيه نياسين ، ل وهلاتهكيّ

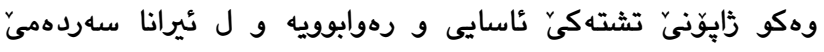

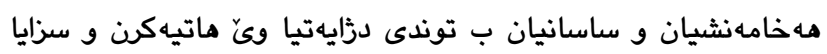

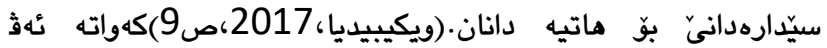

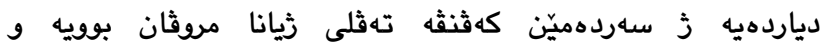
بهرجستهنهبوونا هاثره كهزخوازييّ د ئهدهبياتا مللهتهكيدا نابيته بهلكه

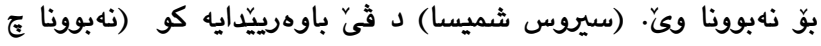
ئامازهيين راستهوخو ب ثيّ دياردهييّ د ئيّكهمين شعريّن كلاسيكييّن

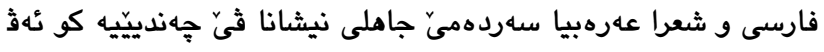
دياردهيه دناث ئيرانييّن كهثن و عهرهبيّن سهردهميّ جاهليدا نهبوويه).

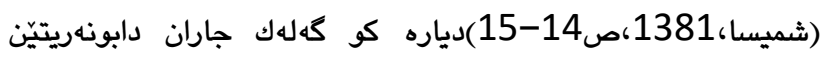

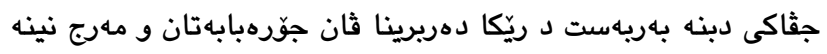

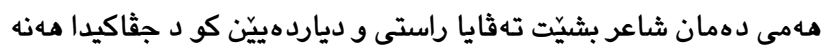

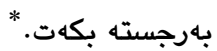
سهرهارى هندى كو ئه د ثيّ باوهرييّداينه كو ئهث دياردهيه ز كهثنترين

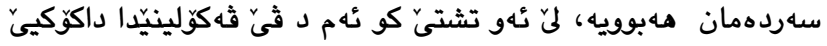
لسهر دكهين بهرجستهبوونا ويّ د شعرا كلاسيكيا رّذّهلاتا ئيسلامييه كو ب ناوايهكي سهرهتايى د ههمبيّزا قهسيدهيا عهرهبيدا خويابوويه و

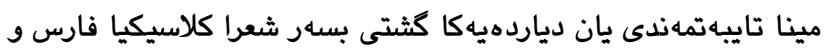
ب تاييهت قهسيدهيا سهبكيّ خوراسانى زالبوويه و پِاشان بو شعرا نهتهوهييّن دييّن دهثهريّ هاتيه ثه گوهاستن.

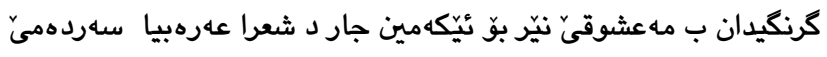

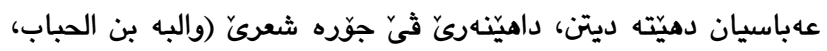
مرن:786ك) بوويه، پپاشى ذ لاييّ قوتابيى ويثه واته (ابو نواس)ى

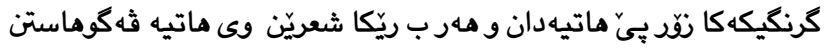

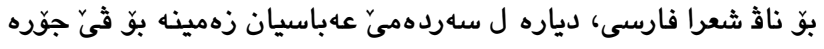

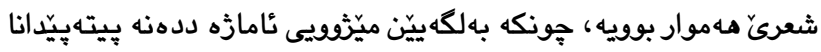

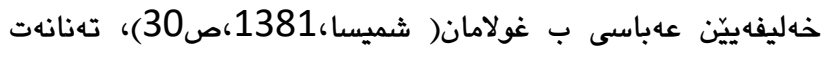

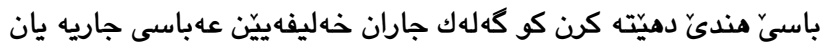

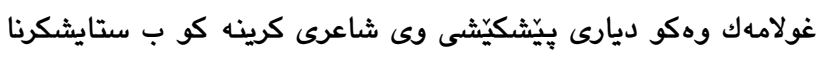

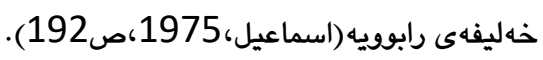

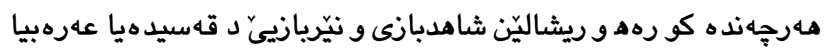
سهردهمى عهباسياندا دهينّه ديتن، لمن ئهث جهنده د شعرا فارسيدا

كه شهكرنا ويّ ددهنه بال تهثليههثبوونا فارسان دكهل توركان، يانكو ب دهربرينهكا

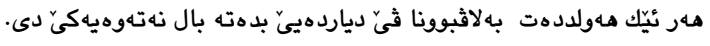

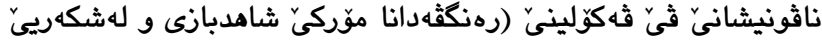
سهبكيّ خوراسانى د شعرا كلاسيكيا كوردى دا)يه.

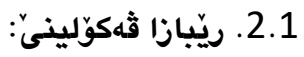
د ثيّ ثهكوَلينيّ دا مه بِتر يُشتبهستن لسهر ريّبازا (وهسفى-

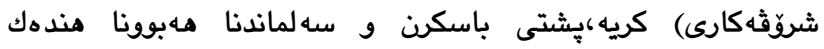

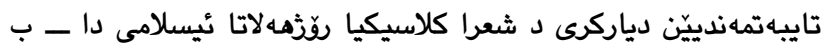

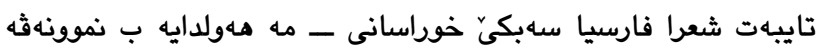
رهنكفهدان و كاريكه ريا وان د شعرا كلاسيكيا كورديدا بدهينه خوياكرن.

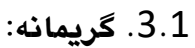

جيّدبيت موّركيّ شاهدبازى و لهشكهريحّ شعرا كلاسيكيا كوردى دياردهكا

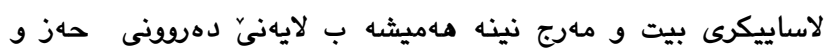
ئهزموونا شاعريثه بهيته كريّدان.

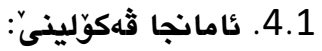
مه دثيّت ثيّ راستيحّ بدهينه دياركرن كو موّركيّ شاهدبازى و لهشكهرييّ

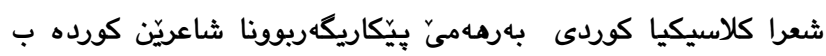
شعرا كلاسيكيا فارسى ب تايبهت قهيديا كورديا سهبكيّ خوراسانى كو ماكا كه شهكرن و وهرارا ثان دياردهيانه.

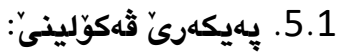

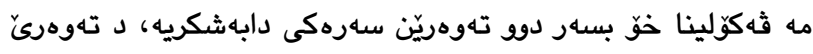

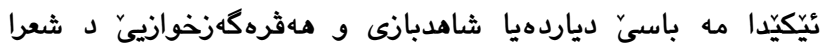
كلاسيكيا رِذْههلاتا ئيسلاميدا و كهشهكرنا ويّ د سهبكيّ خوراسانيدا كريه و پِاشى ب نموونهثه باسيّ رهنكثهدانا ثيّ دياردهيحّ د شعرا

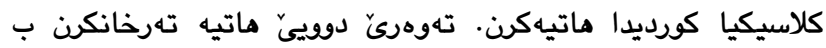
زالبوونا موّركيّ لهشكهى بسهر قهسيدهيا سهبكيّ خوراسانى و بهردهوامبوونا ويّ د سهبكيّن دييّن شعرا فارسيدا، پٍاشى باسيّ رهنكثدانا ثيّ تايبهتمهندييّ و كاريكهريا ويّ لسهر شعرا كلاسيكيا كوردى هاتيه كرن.

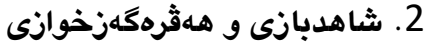

دياردهيا ههثرهكهزخوازييّ تايبهت نينه ب ع نهتهوه يان جثاكين دياركريثه، بهلكو ل هـمى جقاكان ب ريّزَهيين جياواز دهيّته ديتن.

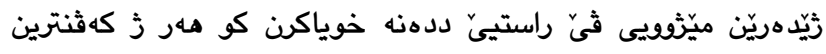

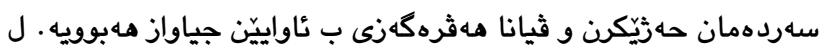

"كه له ك ثهوَله ريّن عهرهب سهرهلدانا فيّ دياردهيَّ د شعرا كلاسيكيا عهرهبيدا ددهنه

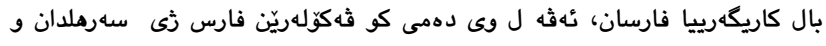




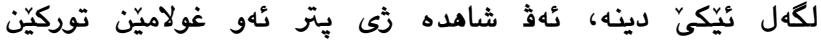

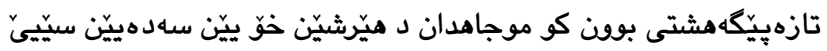

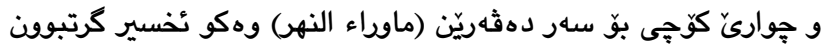

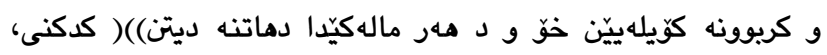

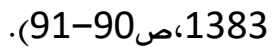

ههرجهنده كو وهرارا دياردهيا نيّريوونا مهعشوقان و شاهدبازى پيتر

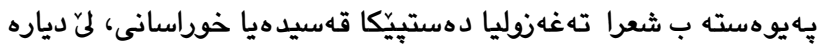

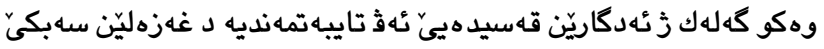
عهراقيدا زى ماتيه پِاراستن (تهنانهت د ئيكهمين غهزهليّن فارسييّن

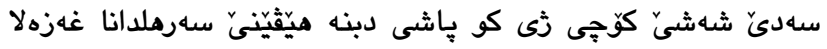

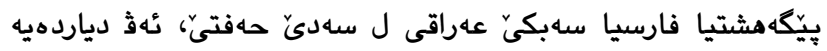

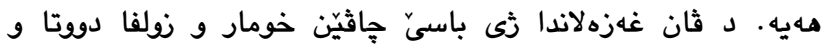

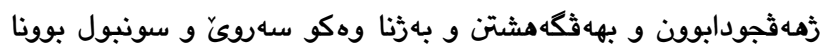

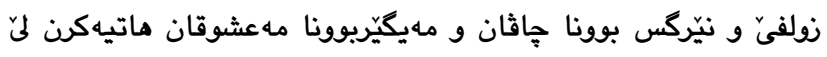

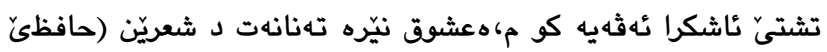

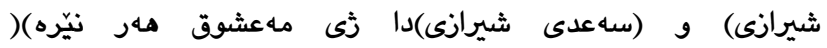

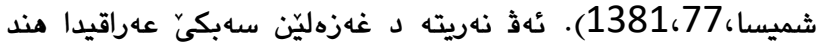
بهيّزه كو( شاعر دهليقيّ ددهته خّ كو مينا مهشوقهكى سهرهدهرييّ

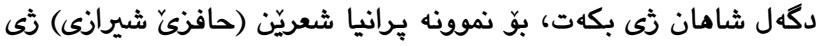

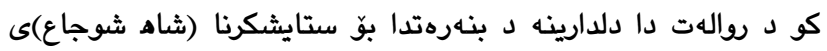

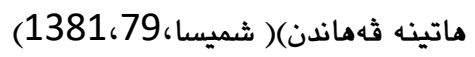

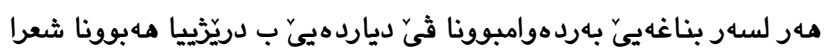

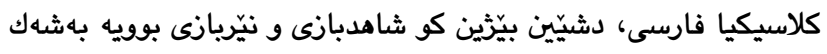

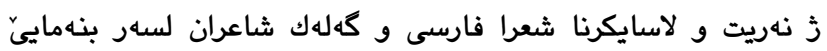

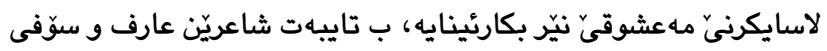

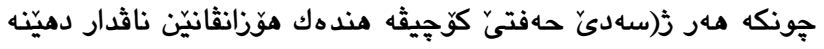
ديتن كو وهسف و يِهسنا هـر سيّ جوّريّن مهشوقان دكهن، واته جار

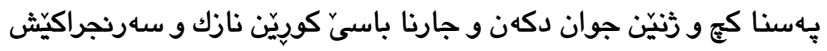

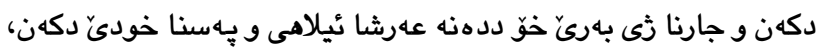

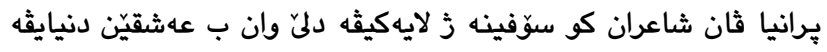

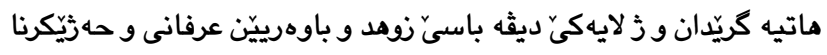

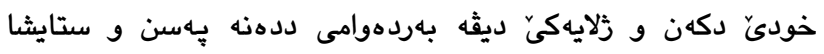

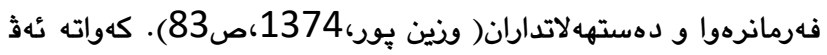

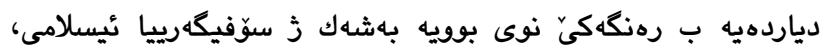

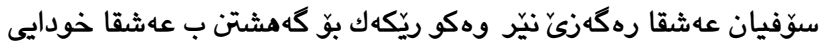
بكارئيناينه، سوّفى د ثيَ باوهرييّدانه كو ئهو دشيّن ب ريّكا ثيّ جوَره حهزيكرنيّ بكههنه حهزيّكرنا حهقيقى يانكو راستهقينه كو حهريكرنا

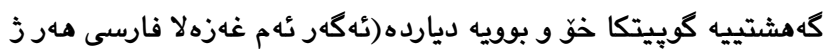

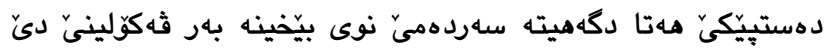

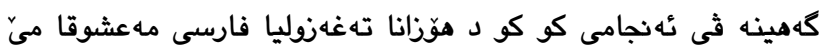

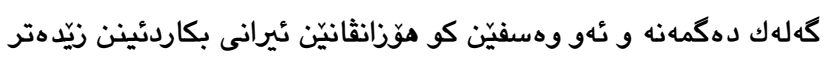

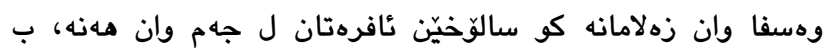

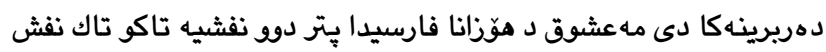

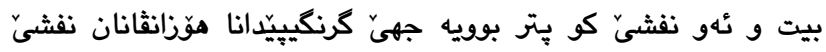

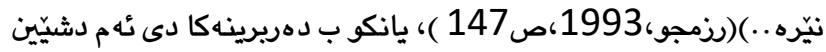
بيّرين ئه ديارده د غهزهلا فارسيدا ب بهردهوامى ههبوويه و ل سهدان

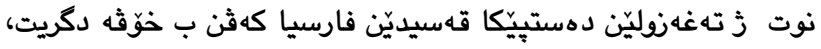

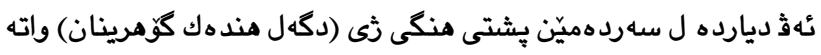
د هوَزانيّن هوَزانقانيّن ناثداريّن وهكو حافز و سهعديدا ثَى بهردهوام

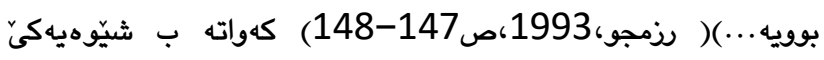
كثتى نهذ تايبهتمهنديه زاله لسهر شعرا كلاسيكيا فارسى.

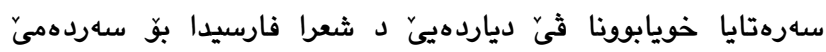
سامانيان دزفريت، ههر جهنده د شعرا سهردهميّ سامانيدا ثامازهكا

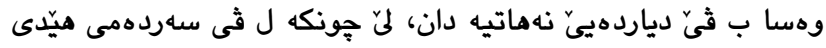
هيّدى غولاميّن تورك د دهولهتا سامانيدا بووينه خودان يِله و پِايهيِّن لهشكرى و روّلى خوّ ديتينه، لهوما جارنا شاعران باسيّ جوانى و سهرنجراكيش بوونا ثان غولامان كرينه، ب ثى نئاوايى نامازهيين

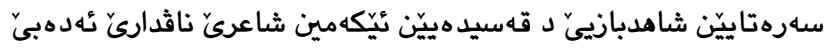

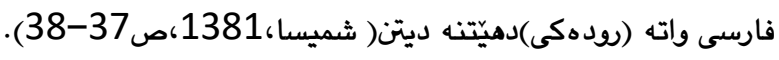

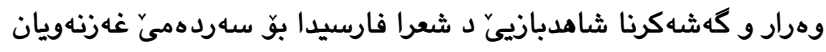

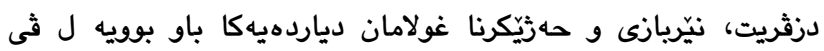

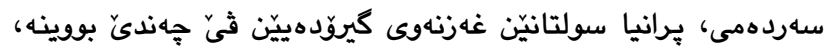
تهنانهت (سولتان مهحموديَ غهزنهوى) ذَى غولاميّن خُّ هـبووينه و

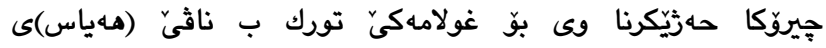

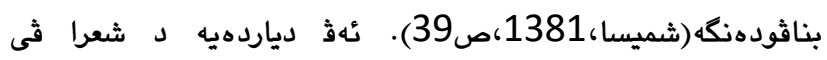
سهردهميدا ههتا وى رادهى بهيّزه كو دشيّين بيَّرين (د هوَزانا سهردهمي

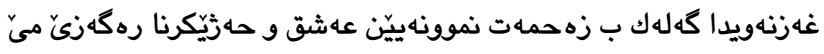

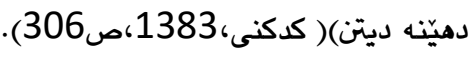

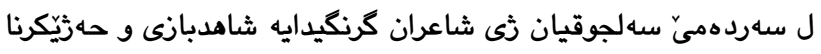

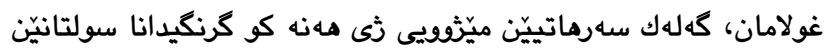

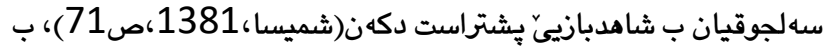
ثى ناوايى بِرانيا شاعريّن قهيدهنفيسيّن سهبكيّ خوراسانى واته يِّن وهكو ((فهرخى، موعزى)،مهنوجهرى و وئهوهرى و ...هتد، ئهو شاهديّن

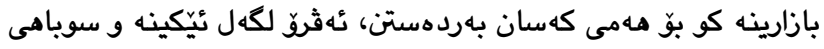




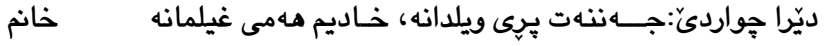

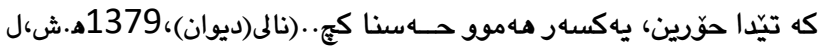

كج و كور دشيّن وهك مهشوق روّلَّ خوّ ببيبنن، يانكو مهر دوو

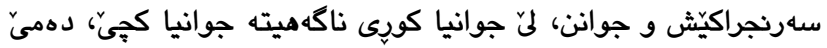
(سهبزه) - كو مهبهست ريه و سمبيّلن - دهردكهثن، جوانيا كوري كيّم دبيت و ناكههيته جوانيا كِيّ. هـر وهسا د ده بهشتيّدا غولمان

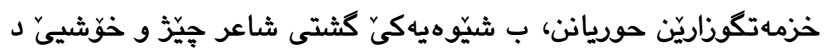

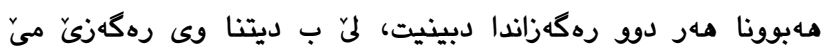
سهرنجراكيشتره، دياره نئه ههلويستى وى بوويه جهى كفتكو و و دانوستاندنا شاعريّن يشتى وى، بو نموونه (ئهدهب) د شعرهكيدا كو

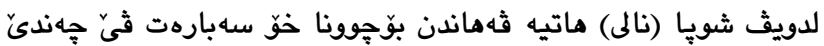

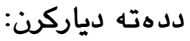

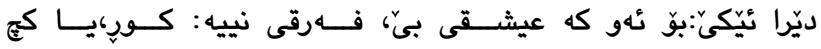

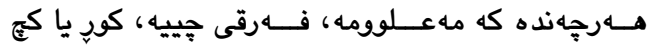
ديّرا جوارىّ:كور، يا كِّى سيمين تهن، هـر دوو كولّى يهك گولشهن

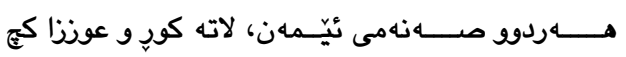
ديّار سيّزدىّ:بيَّ مهر دوو حهرامه عهيش، بَّ روكن و قهوامه عهيش

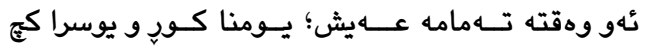

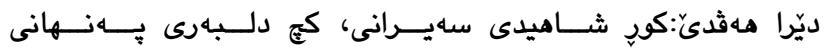

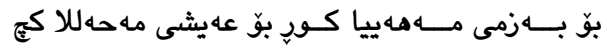

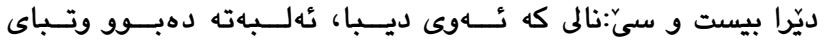

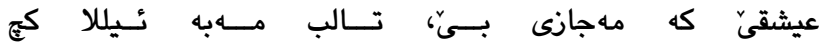

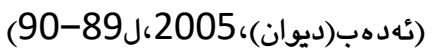

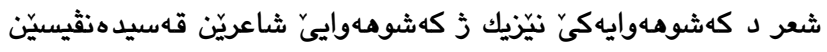
كوّجها سامانى و غهزنهوى و سهلجوقياندا ماتيه يِيشكيشكرن،

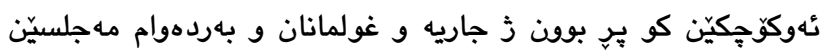

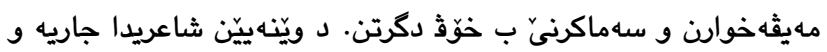
غولمان دهينه ديتن، شاعر داكوكيىّ ل بالكيشبوونا مهر دوو رهكهزان دكهت، كوريّن جوان بوّ دهمى مهستيىّ كونجاون و كجّ بوّ وى دهمى باشن كو مهستيا مروثى دكهيته كوييتكيّ. شاعر ل داويا شعرا خوّ سهرهراى دوويارهكرنا ناخفتنا (نالى) رهخنى ذَّى دكريت كو زيّدهوّيى

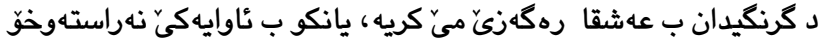
داكوكيى لسهر قيَ جههنديّ دكهت كو عهشقا رهكهنى نيّر عهشقها حهقيقيه يانكو ب دهربرينهكا دى دثيّت جهختى لسهر عرفانى بوونا

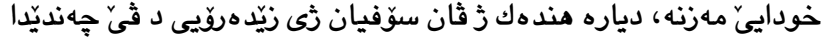
كريه و كهشتينه ثيّ قهناعهتيّ كو تهماشاكرنا كوريِن سنيّله و كويربون د ثي جهه نديّدا مهر وهكو ثيّ جهه نديّيه كو ئهو تهماشهى جوانيا خودى دكهن، يانكو د ثيّ باوهرييّدا بووينه كو خودىّ د ويّنهيِن جواندا

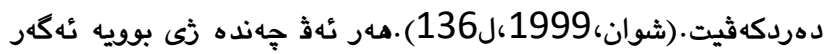

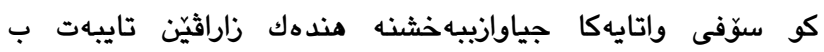

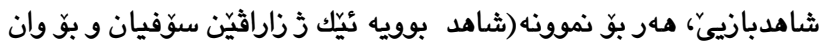
كهان هاتيه بكارئينان كو خودان ديّمهكي جوان و سهرنجراكيّنن و

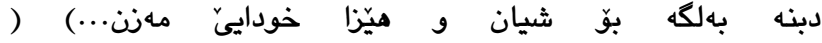
شميسا،1381،ص14). سهرهارى هـولدانا سوَفيان بوّ كَّهرينا ثَّ

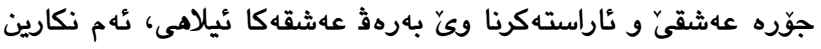

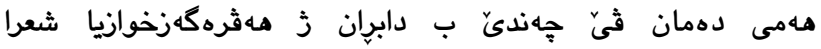
قهسيدهنقيسيّن سامانى و غهزنهوى و سهلجوقيان ل قهلهم بدهين،

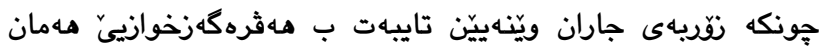
ويَنهيِن شاهدبازيا سهبكي خوراسانيه.

1.2. كاريكهريا شاهدبازيا قهسيدهيا خوراسانى لسهر شعرا كلاسيكيا كوردى:

ثاهدبازى و ثه هاندنا غهزهلان د وهسف و حهريّكرنا رهكهزيَّ نيّر كو د سهبكي خوراسانيدا كهشتيه كويِيتكا خوّ و پاشى كاريكهريا خوّ لسهر

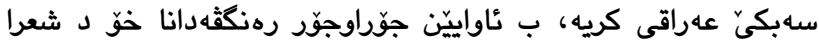
كلاسيكيا كورديدا هـبوويه و يـرانيا شاعريّن كورد كهتينه ثيّ كاريكهريا موركى شاهدبازيَّ شعرا فارسى. تشتى بالكيّش سهبارهت ب رهنگثهدانا شاهدبازى و زالبوونا ويَّ لسهر ديمهنيّن غهزهلا دلداريا كوردى ئهثهيه كو ثاعريّن كورد كهلهك جاران زانينه كو د غهزهلا واندا ئاراستهيهكا مهثرهكهزخوازييّ مهيه، واته

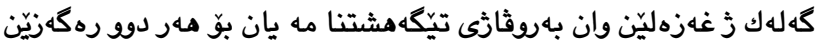
نيّر و ميّ هاتينه ئاراستهكن يان هـثرهكهزخوازى د ثان غهزه لاندا زاله و شاعرى يتر كرنكى ب رهكهزىّ نيّر دايه، دياره كو (نالى) مهست ب نيّربوونا مهعشووقى د غهزهلا فارسيدا كريه و ثيايه هـثسهنگيهكي بيّخينه دناثبهرا لاسايكرنا ثى نهريتيَ شعرا فارسى و سروشتى خِو :

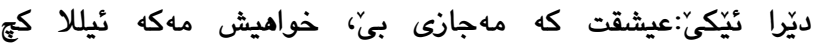
شيـرين كـ و لـهيلا كج و سه لما كج و عهزرا كج

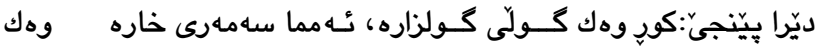

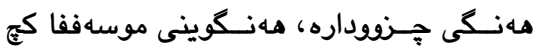

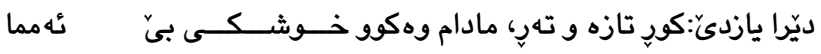

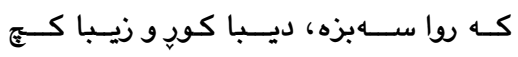




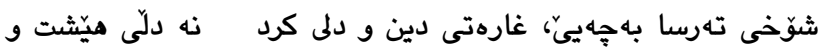

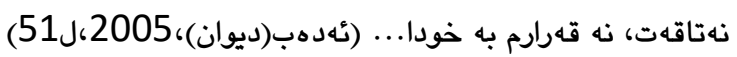

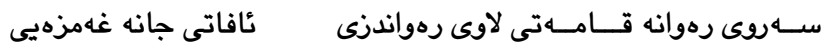

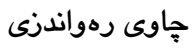
لهو ناسيحانى ئيّمه كه بوّ دلّ دهدهن به دز و دينى لهوان دزى (مه حوى(ديوان)، 1391ه.ش، بـ385)

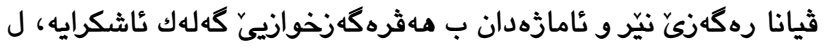

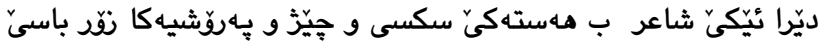

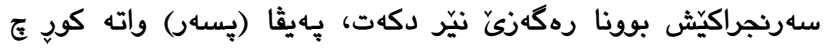

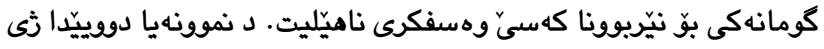

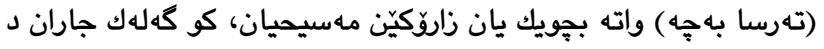

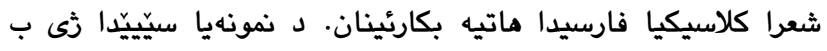

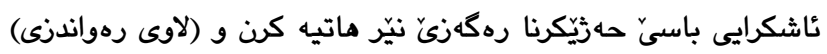

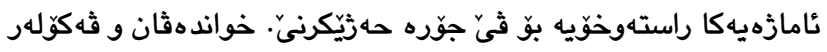

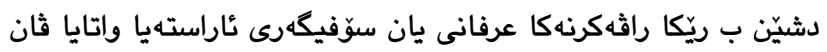

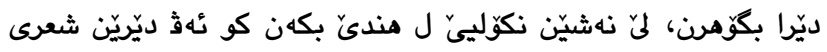

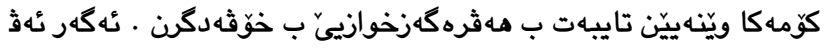
نهريته د شعرا كلاسيكيا فارسيدا باو نهبا؛ شاعريّن كورد ثى نهدشيان

وهسا ب رُّهنى و ئاشكرايى ثان ويّنهان بِيشكيّش بكهن.

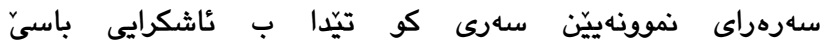

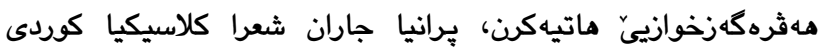

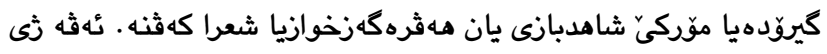

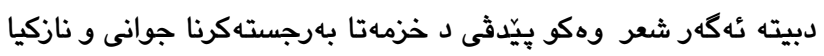

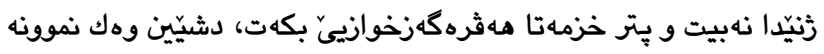

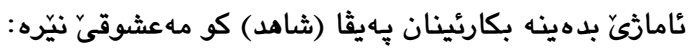
وهه كو بيَّ شاهد و مهحبوب ته عومريَّ خوه بوار كـارهكى رابه

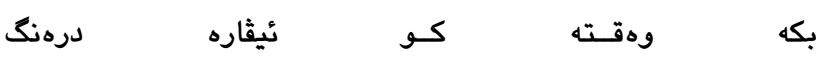

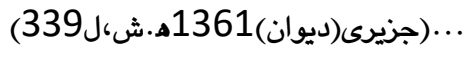

شاهد و ساقى و موطرب كو ل وى جهمع دبن خ خوه صوحبهتئ

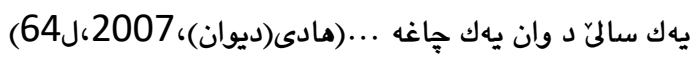

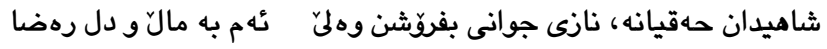

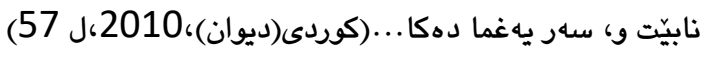
شاهد ئامازهدانهكه بو حهريككن و ثيانا رهكهزيَّ نيّر، ئهث ويَنهيه

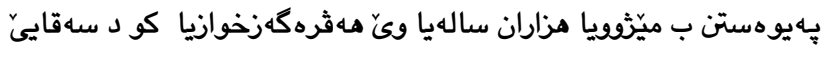

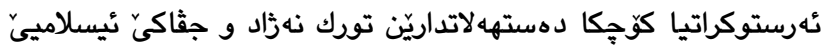

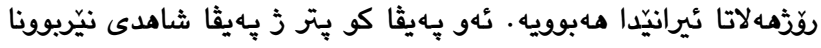

عهشقا رهكهزيّ نيّر بكهت ، دياره كو (حهريق) ب ئاشكرايهكا زيّدهتر

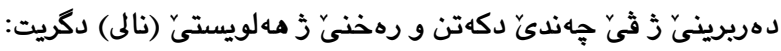

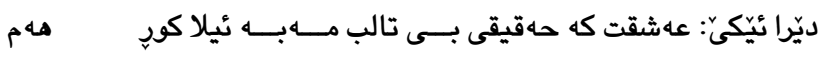

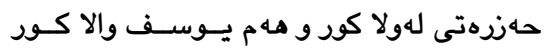

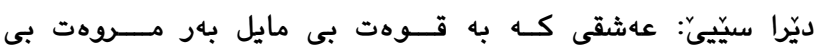

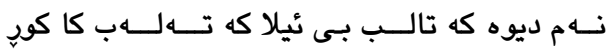

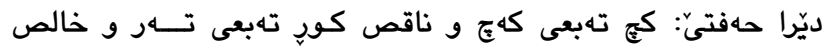
هه م صوحبهت و هل م جالس خوّش منظوره سيما كوري ديّرا يازدىّ: قامهت كه وهكو نهى بى كيّ ديويه له گهل بهى بى بـ

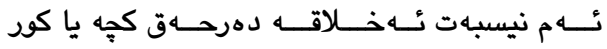

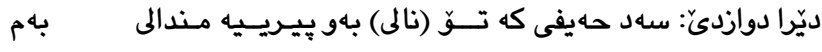

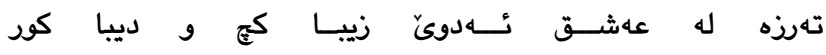

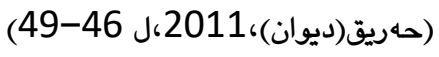
(حهريق) دثى ديتنا ناليه و جهختيّ لسهر ئاراستهيا تهقليديا شعرا

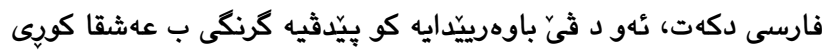

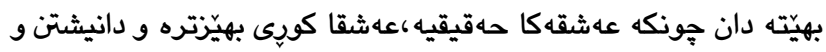
تيّكهلى دكهل كورِين جوان باشتره ذْ وان كهان كو سروشتيّ وان تهواو راسته كو د ثان نموونهياندا جياوازى دناثبهرا بوّجوونا هـر سيّ شاعراندا

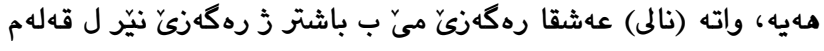
ددهت و ئهدهب د ثيّ باوهييّدايه كو كورِ بو عهشقا حهقيقى و كج بو بو

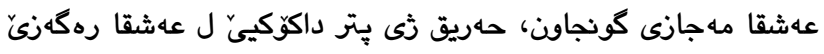

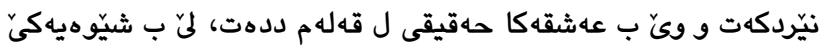

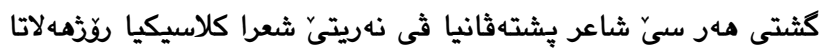

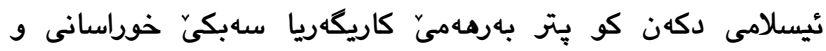
بهردهوامبوونا ويّ د غهزهلا سهبكيّ عهراقيدايه.

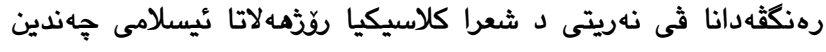

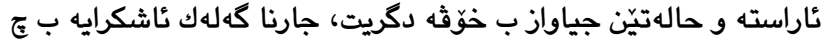

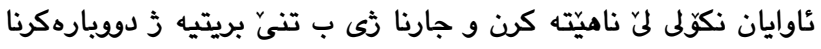

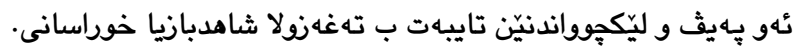
شاهدبازى يان هه ثره كه زخوازى ب ئاشكرايى د ثان نموونهيان دا دهيتّه

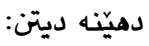

شيرين وهكو خوسرهو يسهرى هورمزه جافه جاو مامزه ليّو قرمزه

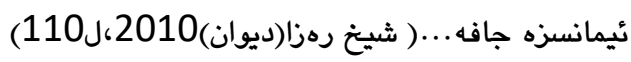


ل ثيّريَّ (خهت) يانكو داثيَن تازه شينبووييّن ريه و سمبيّلان ناسخيّ

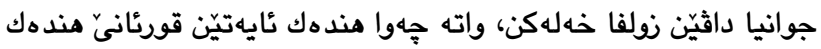
ئايهتيّن دى نهسخ دكهن خهتيّ سهبز ثى جوانيا ديّميّ مهاعشوقى

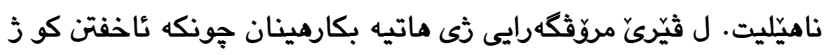

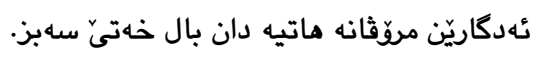
حهماييل كه دهمى تيغت له حهلقهى گهردنى مهكهر تيّراو ببم بهو رهنكه،تينووى ساعيدى يارم...(نالى(ديوان)،ه. ش1379،13، ل286) بكارينانا (دهمى تيخ) زيّدهتر لكهل ساخلهتيّن مه عشوق يان دلداريَ نيّر دكونجيت، دهث و ليّث ب تيخ يانكو كيّرىّ ماتيه ليَكِواندن، ئهثه ثى ثيه وان داثيّن ريه و سمبيّلان كو تيثن و كهردهنا شاعرى بريندار دكهن.

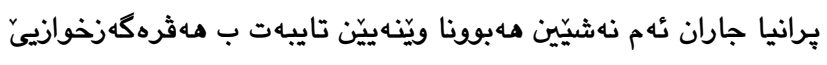

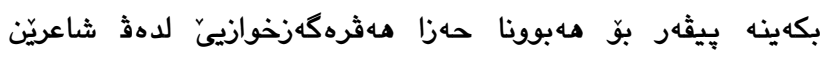
كلاسيكيين كورد يانكو وهكو كهلهك ذ ويّنهييّن دييّن شعرا كلاسيكيا

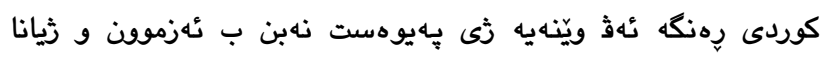

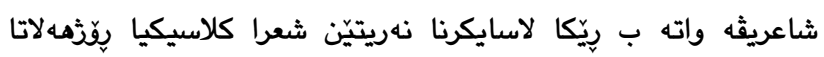

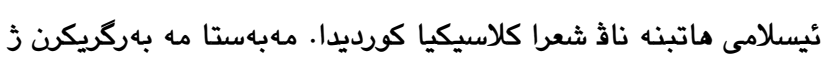
شعرا كلاسيكيا كوردى نينه. ئهم دثى باوهرييّداينه كو هيّدبيت كهلهك

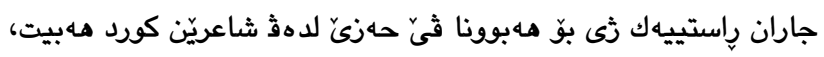

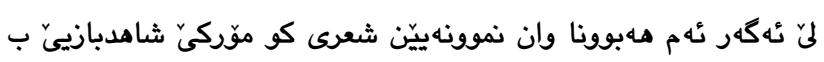
وانثه دياره بكهينه بِيثهر بو مه ثرهكهزخوازبوونا شاعرى بِيّويسته يان يرانيا شاعريّن كورد ب نيّرباز ل قهله م بدهين يان وان ب سوّفى و عارفيّن

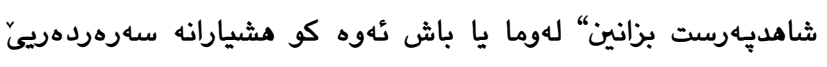

$$
\text { لكهل نموونهييّن ب ثى رهنكى بكه ين. }
$$

نكوّلى ل هنديّ ناهيّته كرن كو شاهدبازييّ كاريكه ريهكا مهنن كريه سهر شعرا كلاسيكيا كوردى و بوويه جوّره نهريتهك، واته مهمى دهمان

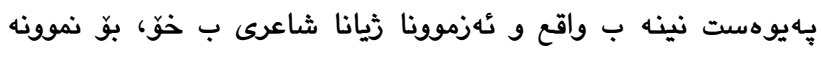
هنده جاران مهد وهكو شعرا فارسيا سهبكيّ عهراقى ب تايبهت شعريّن حافزى د ستايشكرنيّدا ثى هـمان سالوّخيّن كو بو ئافرهتى دهيّنه بكارهينان دهيّنهان بال زهلامى ذَى. ئهم دشيّين وىّ شعرا (كوردى) وهك نموونه بيبنين كو تيّدا يِيروزباهيا جهرنىّ ل (عوسمان بهگَّ بابان) دكهت: جانا وهره ئهم جهزْنه به قوربانى سهرت بم بوّ تيرى قها جهاوى حهسوودان سويـرت بم
عهشقا شعرا كلاسيكيا كوردى بهرجسته دكهت (سهبزه) يان(خهتى سهبز) يا (خهتى نهوخيزه) ، ئه ويّنهيه ( د قهسيده و غهزهلا فارسيدا هاتيه بكارئينان، مهعشوقى نيّر بهرى ريهيّن وى بهيّن جوان و

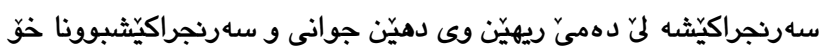

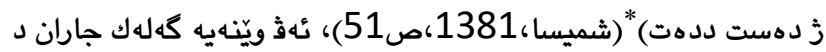
شعرا كلاسيكيا كورديدا ماتينه بكارئينان: تا له دهورى ليّوى ئالى خهتتى سهبزى بوو عهيان عاشقانى جومله

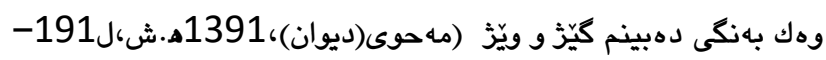

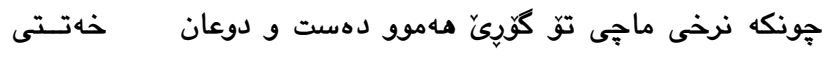

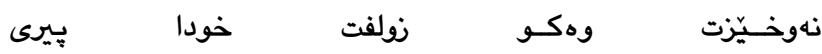
نهكا....(حاجى(ديوان)، 1391ه.ش، وك5)

نولفى بوّ دهفى هوجوومى لهشكهرى سولتانى خهت كهوته خاك و سهركثى دانا وهكو عه مدى ئهله

با وجودى نهوجوانى خهتتى ســـهونى دهركــهـى

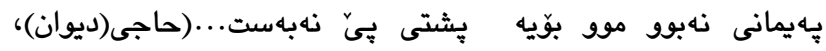

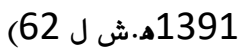

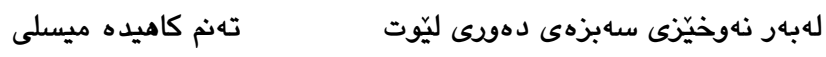
بهركى كايه ...(حاجى(ديوان)، 1391ه.ش ،ل 125) نهشتهى موزكَانى توّ ماتوته سهر سهفحهى دلم هار خهتى بوو،

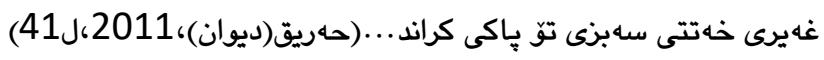

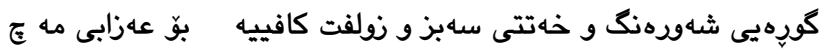

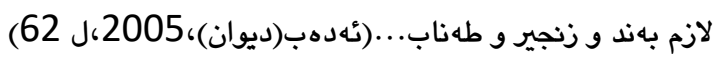

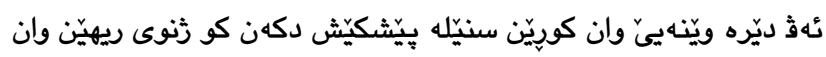
دهيّن، ئه ڤههنده ثى دبيته ئه گهر كو جوانى و بالكيشيا وان وهكو بهريّ

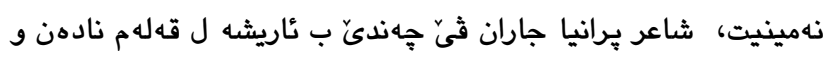

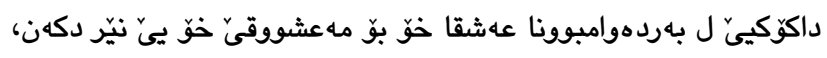

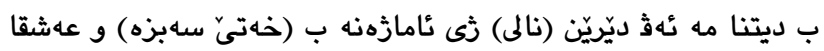
رهكهزَّ نيّر: بروّت بالى هوماى سايهى سهرى سولتانى حوسنت بوو خهتت مات و

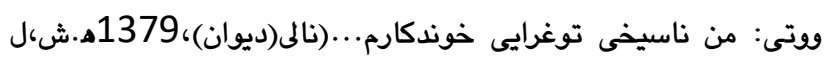
(284

(سيروس شميسا) دبيّزيت كو مهبهست ز (سهبزه) يان (خهتى سهبزه) رهيّن

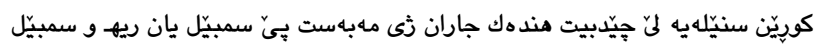

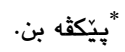


ويّنهيهيّ ديدا جوانيا ثى كويى وهكو جوانيا غهزالهكيّ ل قهله

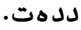

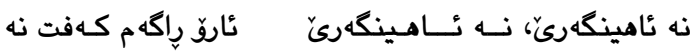

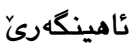

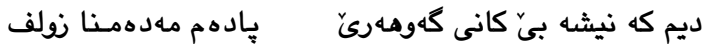

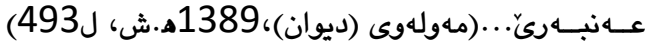

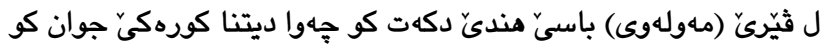

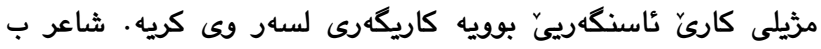
ئاشكرايى باسىّ عهشق و حهرَّكرنا خوّ بوّ ثى كوريى دكهت. نُه كوره

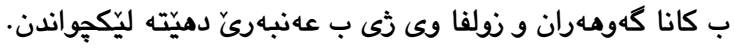
نهو دشيّين بيّزين كو بكارهينانا هندهك ويّنهيِن تايبهت ب شاهدبازييّ

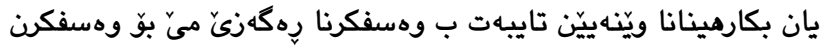

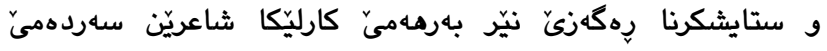

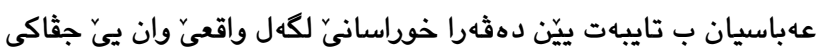
بوويه.شاعريّن يشتى ثى سهردهمى هـر بهردهواميداينه بكارهينانا

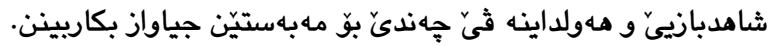

\section{3. زالبوونا موّركى لهشكهرى}

عهرهب ههر ز كهثنترين سهردهمان تهثلى جهنك و شهران بووينه، ههتا وى رإدهى كو دشيّين بيّزين تهايا عهرهبان مثيلى ثى كارى بووينه.

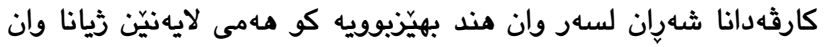
كهفتينه زئر كاريكهريا شهاري، د ناث ثان لايهناندا زمان و ئهدهب پيتر ب

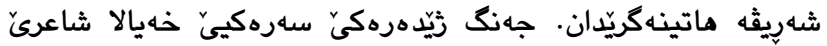

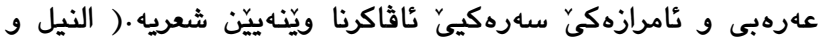

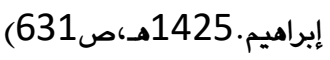

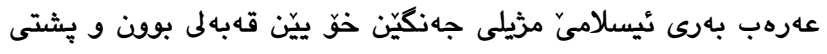

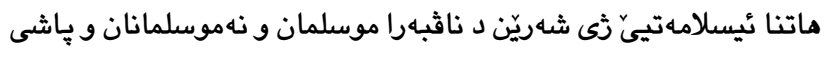

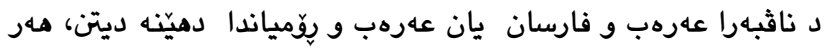

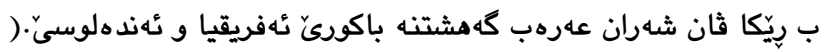
النيل و إبراهيم.1425هـ، ك632). تشتهكى ناساييه كو ئهو شاعرى

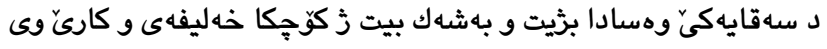
ينّ سهرهكى ستايشكرنا خهليفهى بيت، ديّ كرنكيهكا نقد دهته

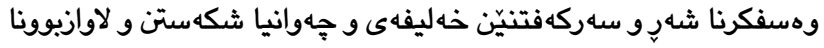
دوزمنان د مهيدانا شهريدا.

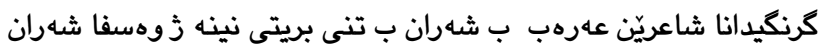

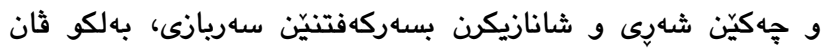

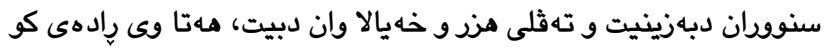

شادن له تهماشاى نهثهرت مهحرهم و ئه غيار مروهت نييه تهنها هـر

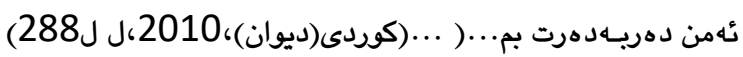
وهكو خوّيايه (كوردى) وهكو مهعشوق سهرهدهريكيّ لكهل (عوسمان

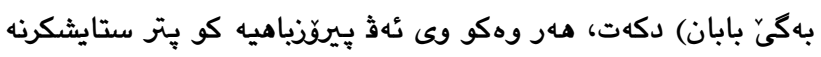

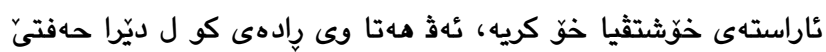
دبيَزيت: بو قهتلى منى خهسته موزهت هلهر وهكو تيره ئهى من به فيداى تيرى نيكاى بِر خهترت بم ...( كوردى(ديوان)،2010،ل ل288) رهنكه لدويث تيّكهشتنا بِرانيا خواندهثانيّن شعرا كوردى ليَكِِواندنا مثيلانكان ب تيران ويّنهيهيَ تايبهت بيت ب وهسفكرنا كاريكهريا جوانيا

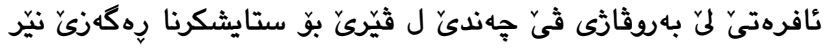

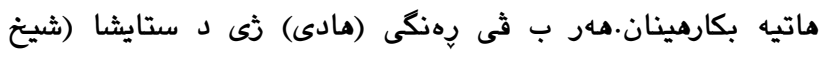
عبدالقادريّ ههزانى) دا دبيَّريت:

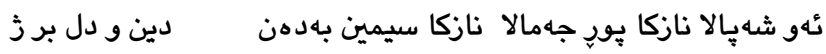

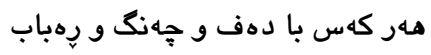

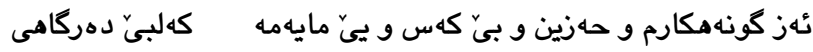

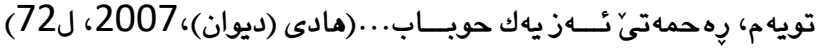

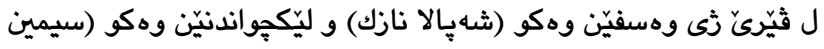
بهدهن) بو سالوخدانا (شيخ عبدالقادريّ ههزانى) هاتينه بكارهينان و ئامازهنه بو بهردهوامبوونا موّركيّ شاهدبازيحّ د شعرا كلاسيكيا كوردى.

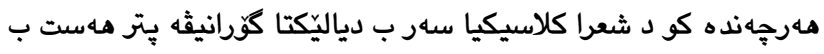

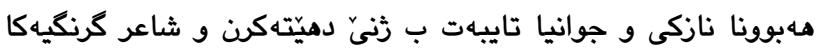

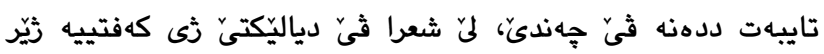

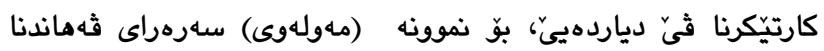

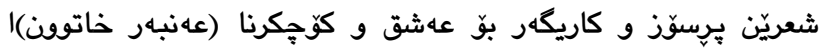

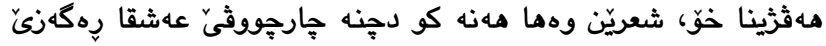
نيّر، ئه خُهنده د دوو شعريّن ويدا ب ئاشكرايى دهيّته ديتن:

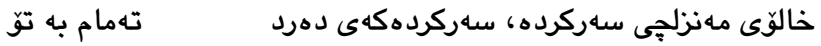
بيّ، ناى يه جِيشت كهرد

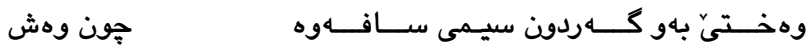

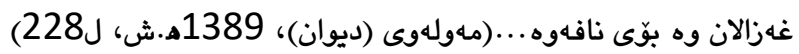

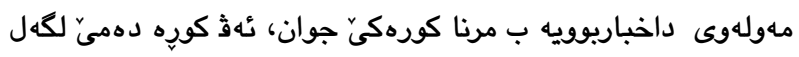

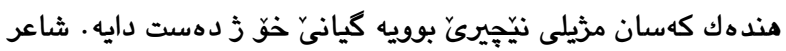

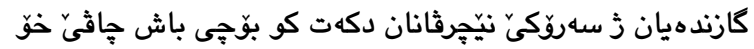

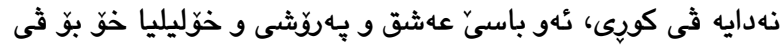

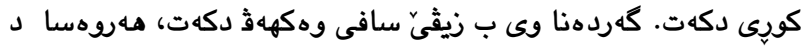




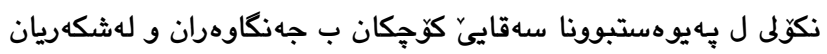

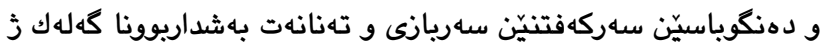

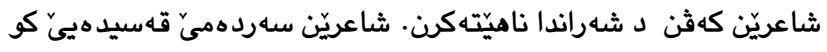

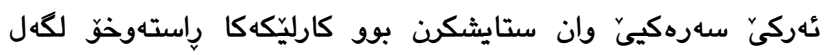

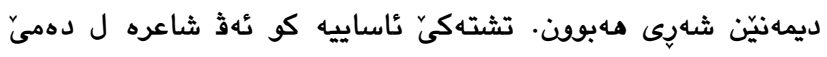

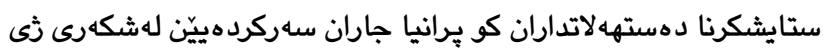

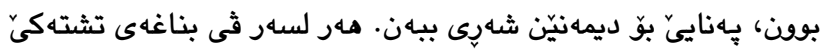
ئاساييه كو ئهث جهنده د شعرا فارسيا سهبكى خوراسانى ثى كو لسهر بناغهيَّ لاسايكرنا قهيدهيا عهرهبى و د سهقاييّ كوّجكاندا سهرهلدايه

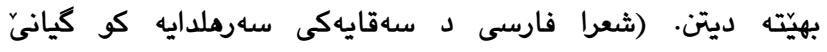

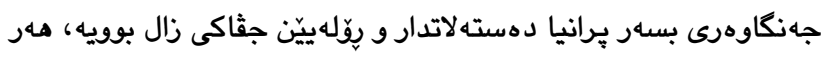

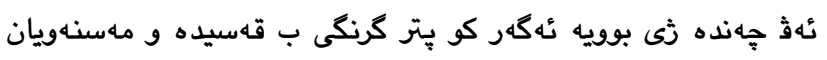

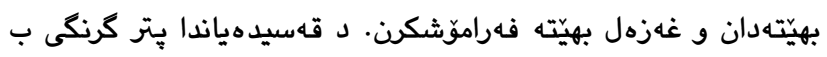

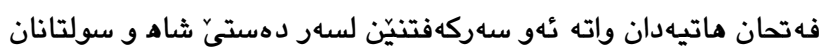

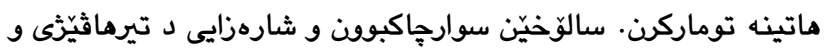
بكارهينانا شيرى بو ستايشكرنيّ ماتينه بكارهينان). (نعمان،شبلى.

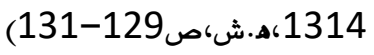
د شعرا فارسيدا ذى هـمان كاريكهريا شهري لسهر شعريّ دهيته ديتن،

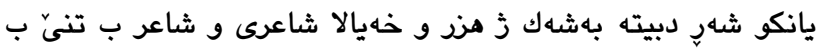

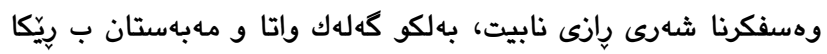

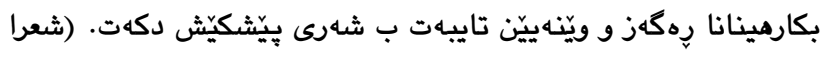

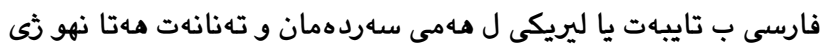

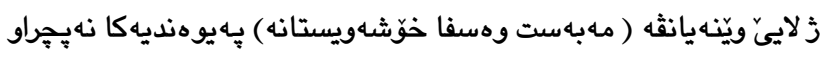

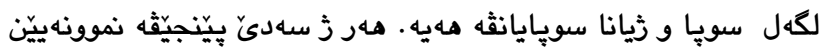

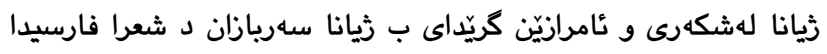
دهيّنه ديتن و ل سهردهميّن بشتى هنگى ذیى وهكو نهريت يانكو لاسايكرنهكا ئهدهبى ئه جههده د ناث شعرا فارسيدا بهردهوام بوويه).

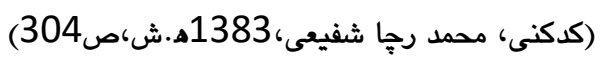

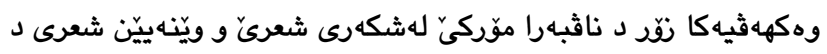

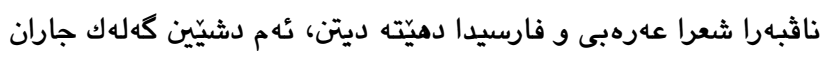

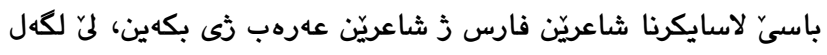

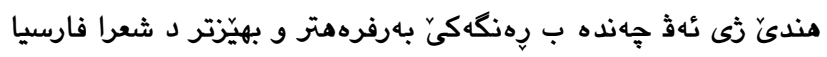

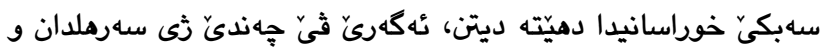

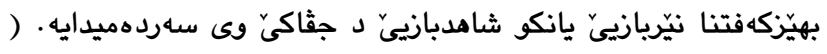

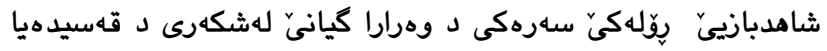

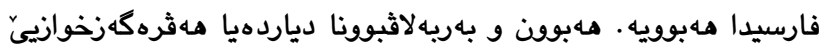

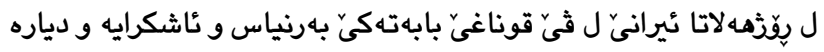

يُّدى شاعريّ عهرهب ب تنىّ ب ريّكا ديمهنيّ شهري كو د هزرا ويدا

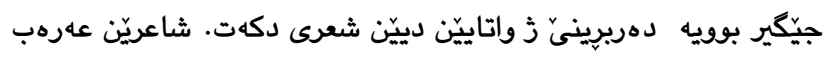

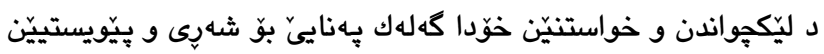

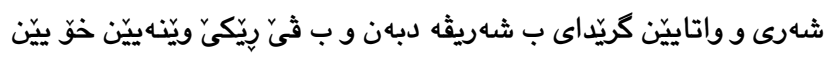

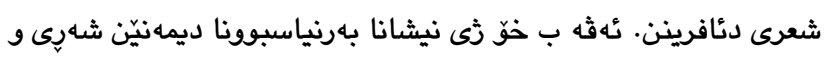

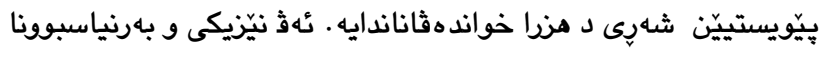

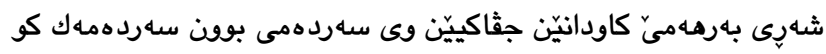
تيّدا شهر لايهنهي سهرهكيى ريانا خهلكى و شاعرى بوويه. ( النيل و

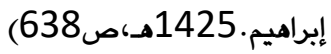
ديمهنيّن شهايى وهكو كوشتن و خوينرشتن ذويّنهيِّن باو و سهرنجراكيّش

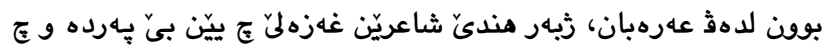

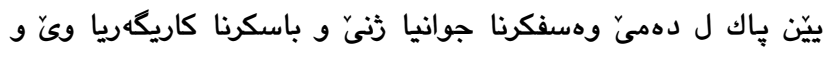

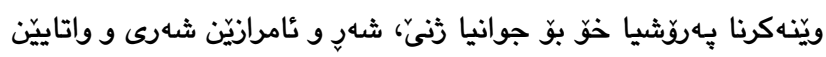

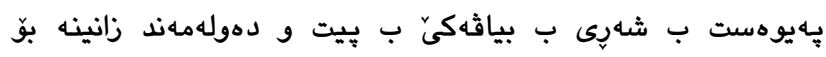

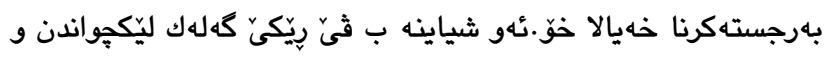

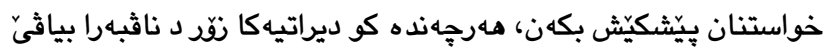

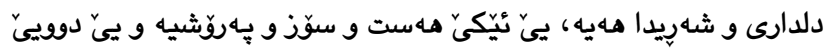

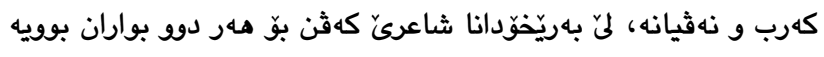

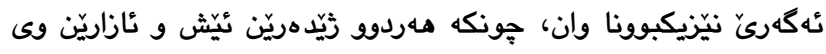

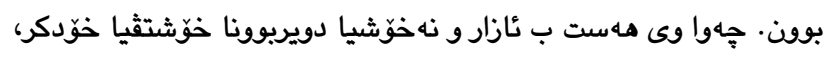

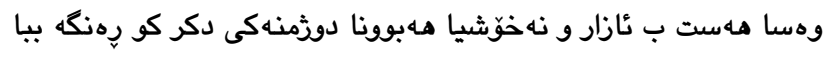

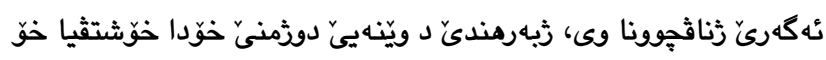

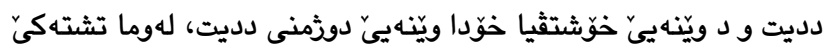

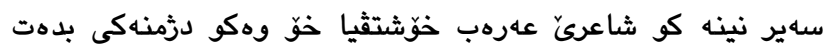
خوّياكرن كو دخوازيت خوينا وى بريَّيت. هـر لسهر فى بناغهى ئهو

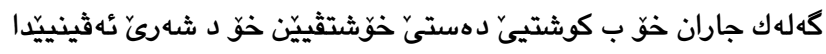
وينه دكهن، واته ئهو دبنه كوشتى و يارا وان دبيت بكوذ و عهشق ثى دئ

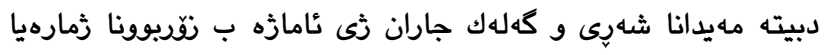

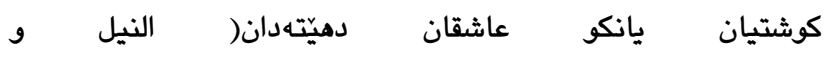
إبراهيم.1425هـ، كوشتيان

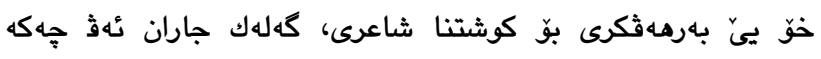

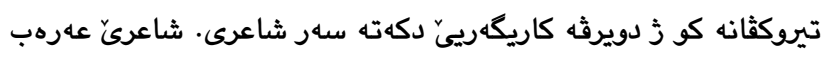
كهله جاران جوانيا خوشتثيا خوّ ب جه كيّن شهرى وهسف دكهت، واته

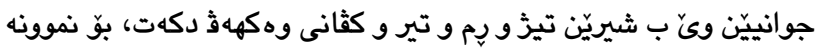

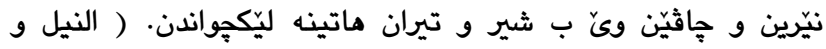
إبراهيم.1425هـ، نو646-648) 


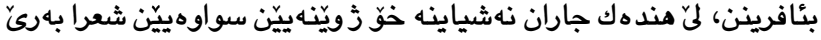

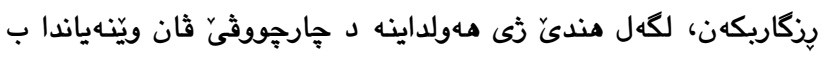

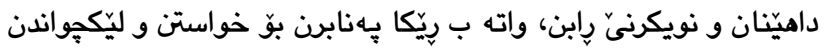

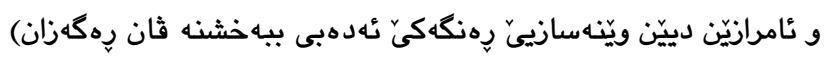
(اكرمى، ميرجليل. 1395ه.ش،ص55)، واته زالبوونا موّركى لهشكهرى لسهر ويّنهيان د شعرا سهبكي عهراقى كو تا رادهيهكي نِّ دويره ز

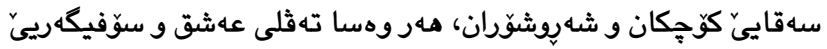

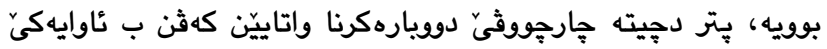

نوى و هندهك جاران ثى دجيته بن سيبهرا لاسايكرنها نيّكاتيث 1.3. رهنكثهدانا لهشكهرگهراييا قهسيدهيا خوراسانى د شعرا كلاسيكيا كورديدا:

د شعرا كلاسيكيا كورديدا ثى كو بهشهكه ز ريّرهويَ لاسايكرنا شعرا

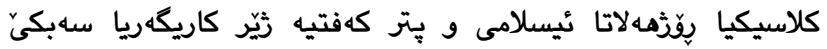

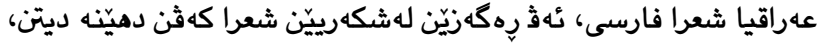
ب تايبهت د ويِنهيِن كريّداى ب دلدارييّهـ. شاعريّن كلاسيكيِين كورد ب ريّكا بكارهينانا ئهو ويّنهييّن كو مؤركيّ لهشكهى لسهر وان زاله كاريكهريا ياريّ ددهنه دياركرن، ئهم دشيّين كهلهك جاران ناويّتهبوونا

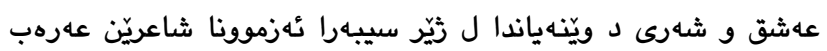
شيوّثه بكهين، لمَ پِهيوهستبوونا بهيّزا شعرا كوردى ب شعرا كلاسيكيا فارسى مه بهرهث مندىّ هان ددهت كو هزرا خوّ د بهردهوامبوونا موّركيّ لهشكهريحّ شعرا فارسى كو تيَكهله لكهل شاهدبازييّ ثى بكهين. د شعرا

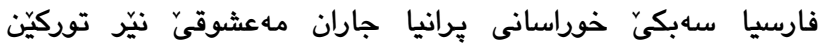
لهشكهرينه، واته ئهثه بهشهكه ز واقعى سهبكيّ خوراسانى كو د شعريّن

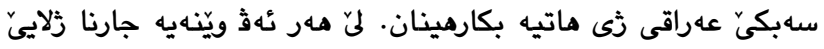
شاعريّن كورد ثى هاتيه بكارهينان:

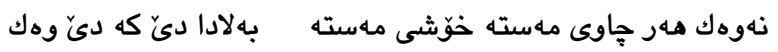
توركى مهسته (مهحوى(ديوان)،1391ه.ش،ص هـ 104) ل ثيّرىّ شاهدبازى ب موّركى خوّيى له شكهرى و جهنكاوهرى خويادبيت،

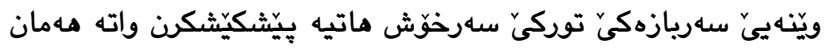
سهربازيّن تورك كو سهرهراى جوانيا خو مهترسيدار بوون و كهس

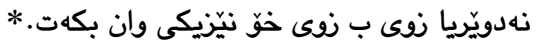
(نالى) ثى د وكَّ شعرا خوّدا كو جِيّدبيت بوّ وهـفا سويايىّ ميرنشينى

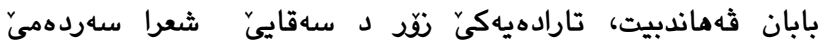

ساختار و عملكرد سياه غزنويان، بِرُوشنامه علوم انسانى، دانشكاه الزهراو،

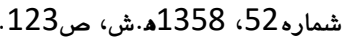

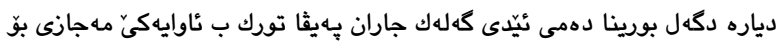

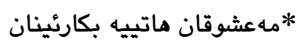

كو هـبوون و بهردهوامبوونا شههران بوويه ئهكهر كو خهلكيّ خوراسانى

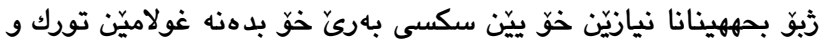

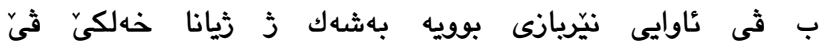

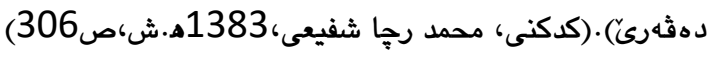
د قهسيدهيا فارسيا سهردهمي غهزنهويان كو ب دهستيّيكا سهردهميَ دهستهلاتداريا توركان د ميّرثوييّدا دهيّته ل قهلهمدان، يِرانيا جاران مه عشوق سهربازهكيّ توركه، لكهل دهربازبوونا دهمى مهر ئهدكاريّن ثان غولامان وهكو قيّرين و بيّ وهفايى و ستهمكاربوون و بحّ سوّزيون و خوينريّزبيونن بوونه تايبهتمهنديِّن مه عشوقان د شعرا فارسيدا، تهنانهت تايبهتمهندييّن لهشى ذى هـر تايبهتمهندييّن وانن وهكو جاثيّن تهنگ، كهمهر باريك، بهزَنا بلند، زولفا كريّداى، مهر بوّ نموونه كهلهك جاران

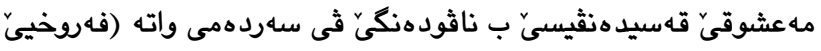
سيستانى) سهرههنكهكه يانكو ز شعريّن وى وهسا خوّيا دبيت كو حهز سهرهـنكهكى كريه*(شميسا،سيروس.1381ه.ش،ص44). ب ثي

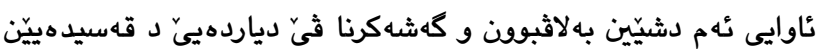
سهبكي خوراسانيدا ب دوو فاكتهرانثه كريّبدهين، ز لايهكيثه مهبوونا

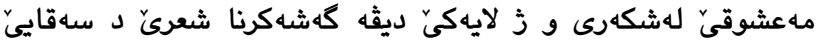
كوّجهاندا و ئاراستهكرنا شعرا ستايشكرنيّ بو وان دهستهلاتداران كو

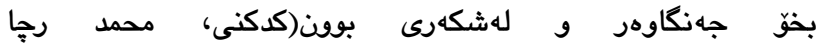

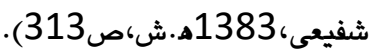
نيّربوونا مهششوقان و مهبوونا غولاميّن جهنكاوهريّن تورك نهرَاد و

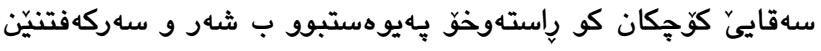
لهشكهرى و داكيركرنىّ، بوونه ئهكهر كو موّركهكي لهشكهرى بسهر قهسيدا سهبكي خوراسانيدا زال ببيت، لمّ تشتى بالكيش ئهثهيه كو

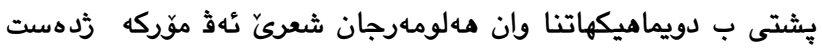
نهدايه و ئهث جهنده وهكو نهريتهك د شعريّدا بهردهوام بوويه. ب

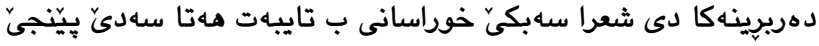
كوجهى زبهر ئهو نيّزيكيا كو لكهل شهارى هـبوو ته ثلى ويّنه و رهكهزيّن شهرى بوويه، لمى يشتى ثى سهردهمى ب تايبهت يشتى لاوازبوونا

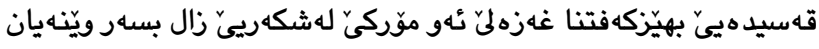
هيتر بريتيه ذ لاسايكرنا شاعريّن سهبكي خوراسانى، يانكو ( لكهل سهرملدانا غهزهلى و وهرارا ويَ د شعرا فارسيدا... شاعريْن فارس هـولداينه ب ريّكا رهكه زيّن سهربازييِن شعرا كهثن هندهك ويّنهييّن نوى

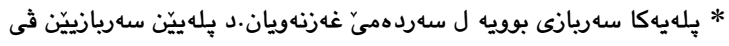

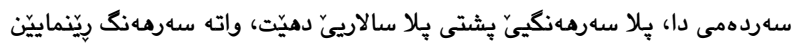

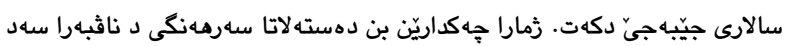
ههتا بِينج سهد كهسان بوويه.بوّ زانيارييّن زيّدهتر بنيّره (حسن زاده، اسماعيل. 
كهسهكه كو دهيّته مهيدانا شهرى و تيران ئاراستهى عاشقان دكهت،

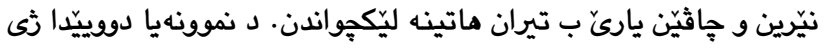

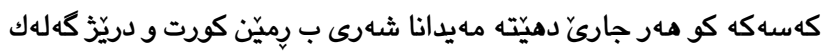
عاشقان دكهته نَامانج، مزراق و قهسهب خواستنهكه كو بوّ جاث و و مزيلانكيّن مه عشوقي ماتينه بكارهينان. مهر ب ثى ثاوايى وهكهاثكرنا

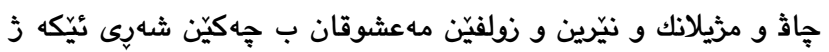

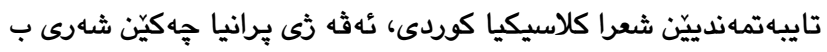
خوّثه دكريت (رم و شه مشير و خهنجهر و تيروكثان و...متد): شاه ب قهصدا كوشتنا من رم مهرزاندن راست و جهه

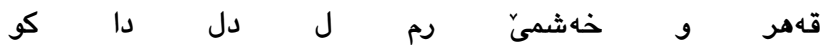
ئهدهب...(جزيرى(ديوان)، 1361ه.ش، ل73)

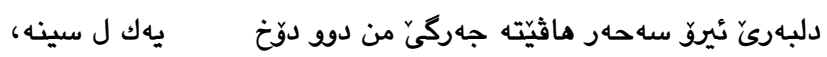

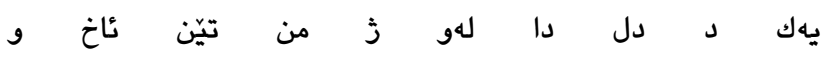
ئوخخ...(جزيرى(ديوان)،1361ه.ش،201) ئهو كه دل دوو قهد دهكا شيرى بروّى ئيكه خهنجه بوّ بهقهد خوّيا

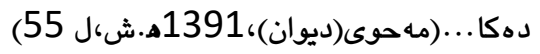

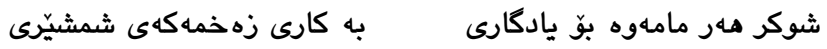
ئهبروت...(مهحوى(ديوان)، 1391هـ.ش، ل112) كرفتارم به نازى جاوهكانى مهستى فهتانت بريندارم به زهبرى

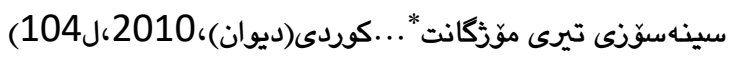

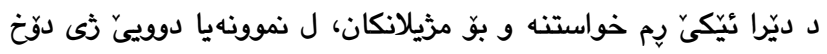
خواستنه بوّ نيّرينا يارىّا، ل نموونهيا سيّيَّ و جواريَّ ثى بردّ ب شيرى ماتيه ليّكِواندن.

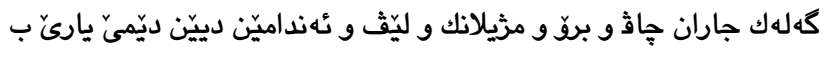

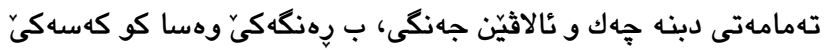
شارهزا د شعرا كلاسيكى نهبيت ههستى ب غهزهليبوونا ويّنهى ناكهت:

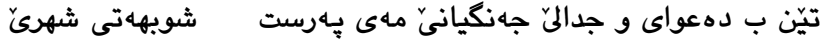
ثيان و يورِ درهخشان راست و جهِي

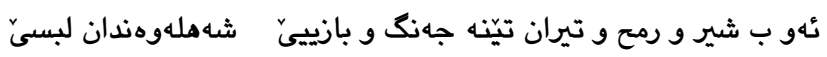

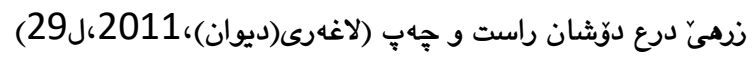

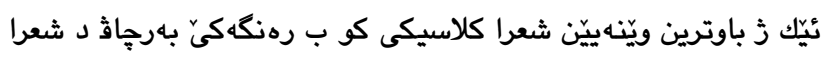
كوردى دا ماتيه لاسايكرن، سالوّخدانا ديّمى يارىّ ب مهيدانا شهريّ نهتهوه و دهولهتانه كو ب ئاواييّن جوّراوجَر ز لاييّ شاعرانثه ماتيه بكارئينان:
غهزنهوياندا دريت، ئهو شعريّن كو تيّدا وهسفا جهنكاوهريّن تورك دهاته كرن، ئهويْن زَلايهكيثه جوان و سهرنجراكيّ بوون و ز لايهكي ديثه جهنكاوهر بوون: - جن

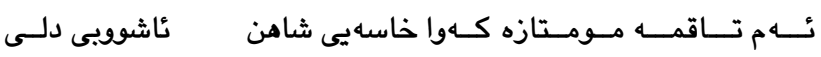
مــهــلهكـهـت و قــهلبى سوياهـن سهف سهف كه دهوهستن به نهزهر خهتتى شوعاعن حــــــه كــ

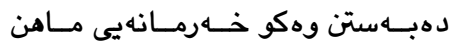

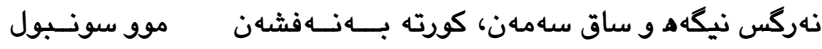
و رومبــات كــول و مه م لاله كولاهن

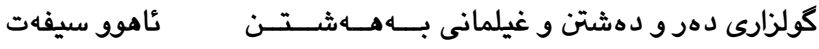

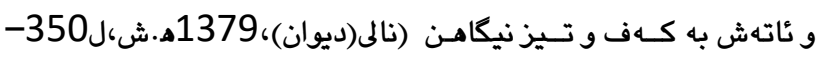

ئهث سوياييّ كو (نالى) وهسفا وى دكهت يـت نيّزيكى وان وهسفانه كو بوّ سويايكّ سولتان (مه حمود غهزنهوى) يان (مهسعودىّ غهزنهوى) دهاتنه بكارهينان، كوّمهكا كهسان كو ز لايهكيثه سهرياز و جهنكاوهرن و ز لايهكى غولاميّن جوان و سهرنجراكيشن، ل دهميَ شهرى ق قهرهمانانه دجهنكن و ل دهميّن دى ثَى دبنه ئالاثهك بوّ رابواردن و خوّشكُوزهرانيا ده سته لاتداران. ليَكِيواندنيّن وهكو (نهركس نيگهه، ساق سهامن، كورته

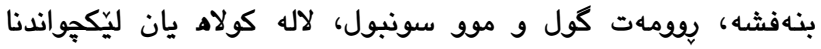

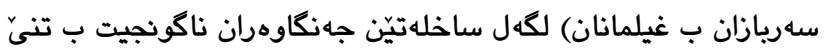
ل وى دهمى نهبيت كو ب نيّرينا شاعريّن سهبكيّ خوراسانى تهماشهى

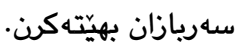
د شعرا كلاسيكيا كورديدا ثى جارنا مهر لدويث نهريتيّ تهغهنولا باوا سهبكي خوراسانى يار جهنكاوهرهكي دهستههله كو د مهيدانا شهريدا

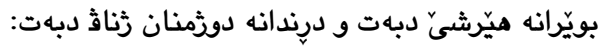
جهندى كو خويان بيّنه رهزم،من ثَّ د دل دانن كَزم ئامانجيّ وان رهمزان

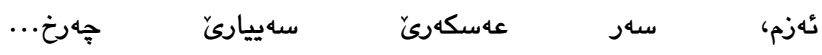

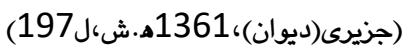

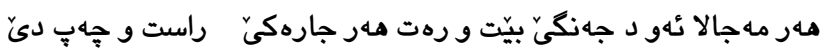

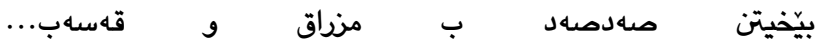
(جزيرى(ديوان)، 1361ه.ش،ل74) ئهو ويّنه و وهسفيّن كو بو ياريّ هاتينه بكارهينان لهشكهرينه، بهردهواميا وان ويّنهيانن كو د شعرا عهرهبيا كهثن مهبووينه و د شعرا سهبكى خوراسانيدا كههشتيه كوييتكا خوّ و پِاشى وهكو نهريتهك د

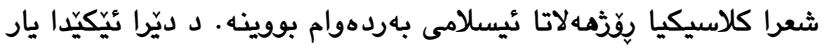

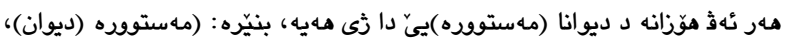

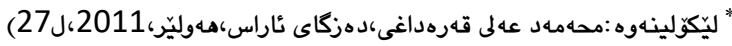


2-2 شعرا كلاسيكيا كوردى دا كهله جاران خوششهويست هه فرهكهز يانكو نيّره، واته تئهو غولامه كو د قهيدهيِن سهبكيّ خوراسانى دا

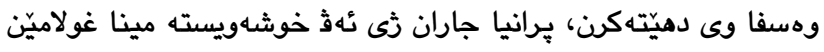

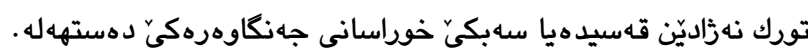

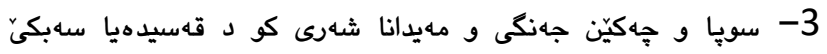

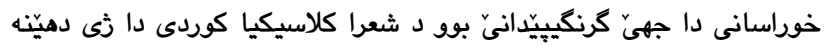
ديتن.

4-مهرج نينه هـمى دهمان ئهو ههثرهكهزخوازيا كو د شعرا كلاسيكيا كوردى دا دهيّه ديتن بهرههمي ئهزموونا راستهقينه و حهزيّن سكسييّن

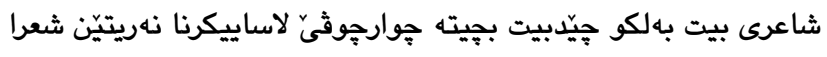
كلاسيكيا بوزّهه لاتا ئيسلامى ب تايبهت شعرا كلاسيكيا فارسى .

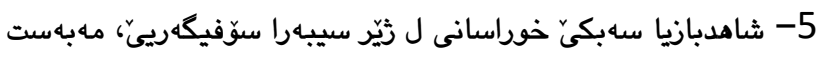

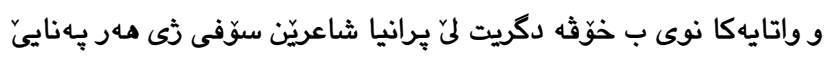
بوّ هـمان ويّنهيِن شاهدبازيا سهبكَّ خوراسانى دبهن.

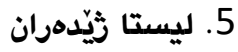

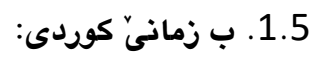

1.1.5 ديوان:

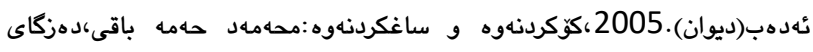

نَاراس،جإِى يه كهم،هدوليّر.

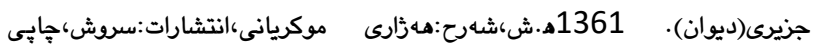

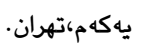

حاجى قادر(ديوان). 1390ه.ش، ليّكَّلينهوه و ليّكدانهوه: سهردار حهميد ميران و

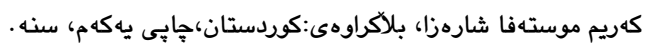

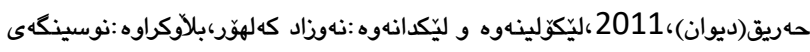

$$
\text { تهفسير، جإيى يهكه م،هدوليّر. }
$$

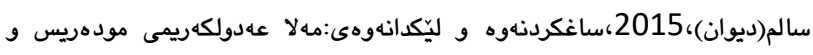

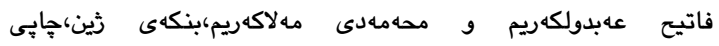

$$
\text { يهكه م،سليمانى. }
$$

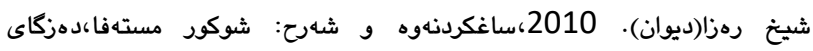
ناراس، جإِى دووهم،هدوليّر.

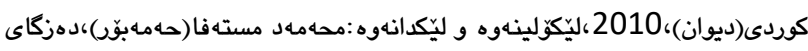
ناراس، جإِى يه كهم،هدوليّر.

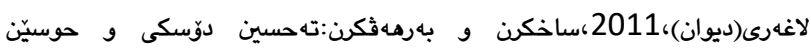

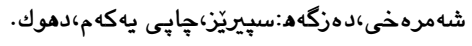

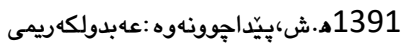

مه حوى(ديوان).

$$
\text { مودهريس،به خشانكاىئانا، جإِى يهكه م،مه هاباد. }
$$

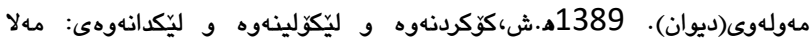

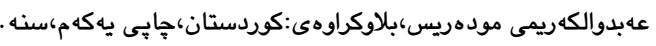

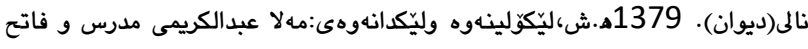

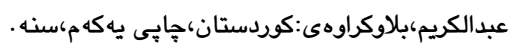

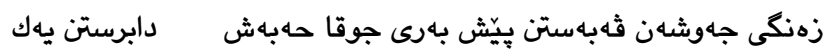

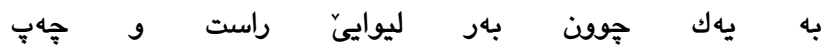

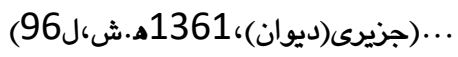

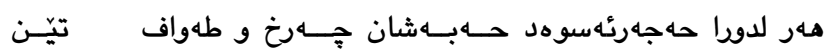

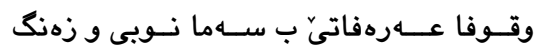
صهف ب صهف تورك و موغول، دوكوش و هيندى دكهمين ب عه جهب

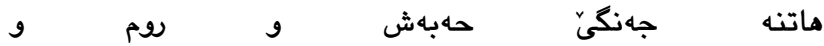
فهرهنگ..(جزيرى(ديوان)،1361ه.ش،ل341-342)

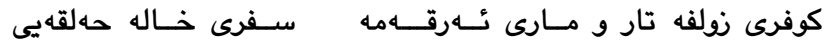
هيندوسيان

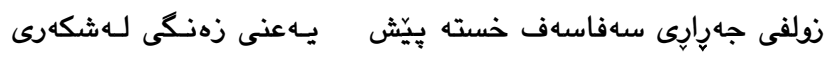

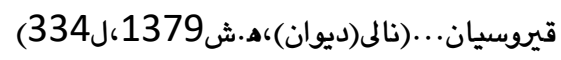
جهيشى حهبهشى نولفى له كهل خهتتى به شهر هات سوّفى دلّى بيّ جاره له بهرييّ بووه هـنجير...(حاجى(ديوان)،1390ه.ش، ل168)

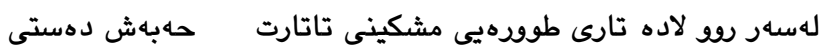
تهطاول با نه كيشى با بهسهر روما ...(سالم (ديوان)،2015،ل125)

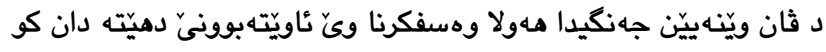

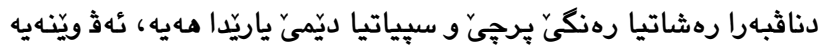

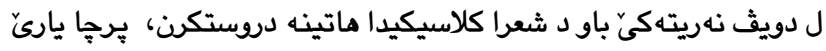
ب سويايَّ نهتهوهيهكيّ رهش يِّيت يان ئهسمهر وهكو حهبهشى يان عهرهب يان زهنكيان و روويى ياركّ نهتهوهيهكي سيى يِّيست وهكو

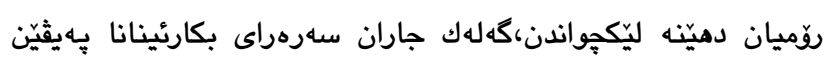

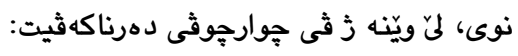
هوجوومى ((هيندوو))ى خهت سهر ((فهرهنگستان))ى رهخسارى به حهشرى بوو، وهكو تئه خهشره ((ميقادو)) به ((جار))ى

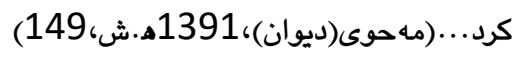
ل ثيّرىّ شاهدبازى و موّركيّ لهشكهرى ته ثلى مهثبووينه . شاعر خهت، واته نُهو داثيّن ريهان كو تازه لسهر ديّميَ كوريّن سنيّله خويادبن ب

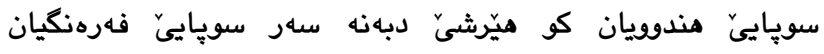

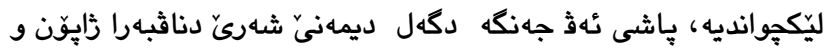
روسيايى وه كهاث كرييه .

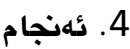

1- شاهدبازى( مهثرهكهزخوازى) و لهشكهرگهرايى مينا نهدكاريّن قهسيدهيا خوراسانى د غهزهل و شعرا ليريكيا قوناغيّن ِّشتى هنگى ثى بهردهوام بوويه و كه هشتيه شعرا كلاسيكيا كوردى ثى. 


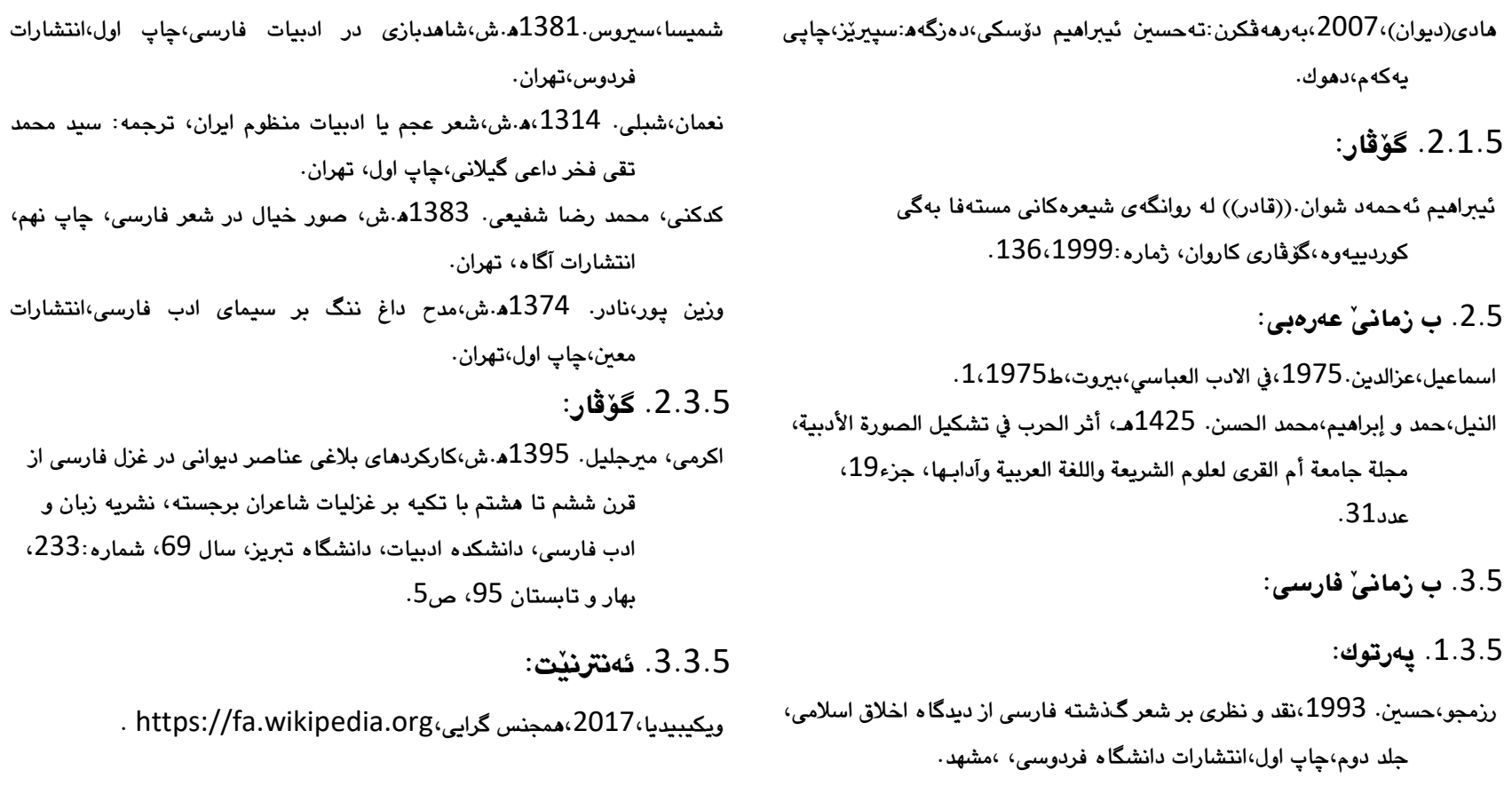

شميسا،سيوس.1381هـش،شاهدبازى در ادبيات فارسى،جاٍ اول،انتشارات فردوس،تهران. نعمان،شبلى. 1314،ه.ش،شعر عجم يا ادبيات منظوم ايران، ترجمه: سيد محمد تقى فخر داعى كيلانى، هابٍ اول، تهران.

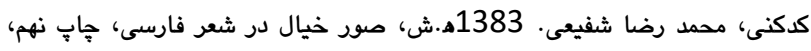
انتشارات آكاه، تهران.

وزين يُور،نادر. 1374ه.ش،مدح داغ نتخ بر سيماى ادب فارسى،انتشارات معين، جإٍ اول،تهران.

2.3.5. كَوْاثار:

اكرمى، ميرجليل. 1395ه. ش،كاركردهاى بلاغى عناصر ديوانى در غزل فارسى از

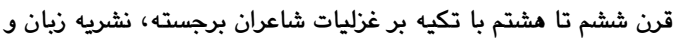

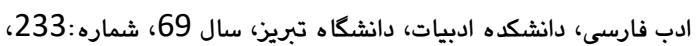

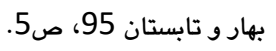

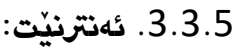

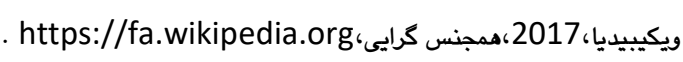

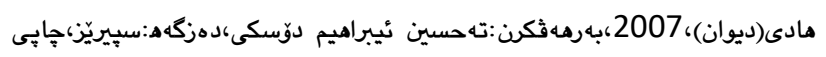

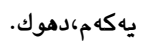

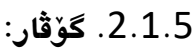

ئيبراهيم ئه حمهد شوان. ((قادر)) له روانكهى شيعرهكانى مستهفا بهىى

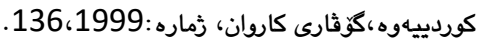

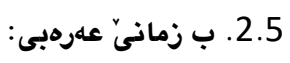

اسماعيل،عزالدين.1975،في الادب العباسي،بيروت،1975،19.1 النيل،حمد و إبراهيم،محمد الحسن. 1425هـ، أثر الحرب في تشكيل الصورة الادبئ الأدبية،

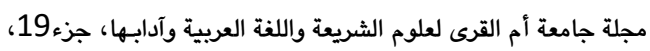

عدد31.

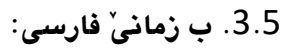

1.3.5. يـهرتوك: - 1.5 رزمجو،حسين. 1993،نقد و نظرى بر شعر كذشته فارسى از ديدكاه اخلاق اسلامى،

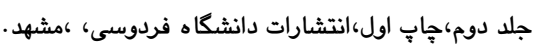


على الرغم من أن نشوء الشعر الفارسي الكلاسيكي مرتبط بمحاكاة القصيدة العربية القديمة و أن الكثير من سمات القصيدة الفارسية في بدايتها قريبة من القصيدة العربية، فان هذا الشعر لديه الكثير من الخصائص التي تعود الى القصيدة الايرانية و بيئتها.و من مذه الخصائص كانت سيادة الطابع المثلية و العسكرية لملوك او سلاطين السامانية و الغزنوية و السلجوقية على التغزل او مقدمة القصائد الخراسانية.في عصر سيادة هذه الدول و نتيجة الغزوات و الهجمات التي قامت بها و وجود الغلمان، كان الافتخار بالعسكرة و الفرسان و لاسيما بالغلمان من اصل تركي يشغل مكانا هاما في القصائد الفارسية و يبدو ان الشعراء الفرس بعد مضي الوقت و لاسيما بعد الضعف الذي دب في اوصال القصيدة الفارسية، قد واصلوا محاكاة هذه الخصائص الى حد بحيث ان الذي كان موضع التغزل لدى الشعراء الفرس كان في اكثر الاحيان غلاما محاريا مثيرا للاهتمام. و قد انتقلت مذه الظاهرة من الشعر الفارسي الى الشعر الكوردي تحت التأثير المحاكاة مذه .و كان الشعراء الكورد يقومون بوصف معشوق ذكرو محارب بصور مختلفة، أو أن الصور الفنية التي كانوا يستخدمونها كانت ثمرة التأثير الذي تركه طابع المثلية و العسكرية للقصيدة الخراسانية. الكلمات الدالة: شاهدبازي، مثلي، عسكرية،محاكاة،اسلوب الخراساني.

\title{
The reflection of shahdazi and military characteristics of Khorasani's style in Kurdish classical poetry
}

\begin{abstract}
:
Although the emergence of Persian Classical Poetry is related with the imitation of the Arabic ancient Poetry, and the features of Persian (qasida) are mostly closed to the Arabic Poetry, hence, this poem has a set of characteristics which are generally the environmental production of Iranian Poetry. One of the characteristics is overcoming the Same-sex character homosexuality and military character of the palace of wealthy, (Samani), (Ghaznavi), and (Seljukian) Authoritative on the (Taghazul) of beginning of (Qasidas). During the reigns of these countries, due to the attacks and invasions that were held by them, the existence of servants and their usage for different purposes, and glorifying the military forces and fighters particularly Turkish ones were occupied the major part of imageries and (Ghazali) expressions in Persian Poets' works. Apparently, by passing periods of time and especially after the weakness of (Qasida) form, Persian poets continued to imitate these characteristics to an extend that the Persian poets were mostly describing a character is referring to a male attractive fighter. So, these phenomena might be the results of transforming the imitation of Persian poetry into Kurdish poetry, additionally, Kurdish classical poets depicted the male fighter-lover variously or the images that were used by them were the production of the impact of homosexuality -military impression of qasida in Khorasani's style.
\end{abstract}

Keywords: shahdbazi,homosexuality, military,imitation, Khorasani’s style. 